\title{
Connexin 43 Hemichannel Activity Promoted by Pro-Inflammatory Cytokines and High Glucose Alters Endothelial Cell Function
}

OPEN ACCESS

Edited by:

Robert Murray Hamilton, Hospital for Sick Children, Canada

Reviewed by: Bo-Zong Shao, Second Military Medical University,

China

Nicolas Riteau,

UMR7355 Immunologie et neurogénétique expérimentales et moléculaires (INEM), France Alex Rafacho,

Universidade Federal de Santa Catarina, Brazil

*Correspondence: Juan A. Orellana jaorella@uc.cl

Specialty section: This article was submitted to Inflammation,

a section of the journal

Frontiers in Immunology

Received: 26 February 2018

Accepted: 31 July 2018

Published: 15 August 2018

Citation:

Sáez JC, Contreras-Duarte $S$, Gómez Gl, Labra VC, Santibañez CA,

Gajardo-Gómez R, Avendaño BC,

Díaz EF, Montero TD, Velarde V and Orellana JA (2018)

Connexin 43 Hemichannel Activity

Promoted by Pro-Inflammatory Cytokines and High Glucose Alters Endothelial Cell Function.

Front. Immunol. 9:1899. doi: 10.3389/fimmu.2018.01899
Juan C. Sáez ${ }^{1,2}$, Susana Contreras-Duarte ${ }^{1,3}$, Gonzalo I. Gómez ${ }^{4}$, Valeria C. Labra ${ }^{4}$, Cristian A. Santibañez ${ }^{4}$, Rosario Gajardo-Gómez ${ }^{4}$, Beatriz C. Avendaño ${ }^{4}$, Esteban F. Díaz", Trinidad D. Montero ${ }^{4}$, Victoria Velarde ${ }^{1}$ and Juan A. Orellana ${ }^{4 *}$

${ }^{1}$ Departamento de Fisiología, Pontificia Universidad Católica de Chile, Santiago de Chile, Chile, ${ }^{2}$ Instituto de Neurociencias, Centro Interdisciplinario de Neurociencias de Valparaíso, Universidad de Valparaíso, Valparaíso, Chile, ${ }^{3}$ Departamento de Ginecología y Obstetricia, Escuela de Medicina, Facultad de Medicina, Pontificia Universidad Católica de Chile, Santiago, Chile, ${ }^{4}$ Departamento de Neurología, Escuela de Medicina and Centro Interdisciplinario de Neurociencias, Facultad de Medicina, Pontificia Universidad Católica de Chile, Santiago, Chile

The present work was done to elucidate whether hemichannels of a cell line derived from endothelial cells are affected by pro-inflammatory conditions (high glucose and IL-1 $\beta / T N F-\alpha$ ) known to lead to vascular dysfunction. We used EAhy 926 cells treated with high glucose and IL-1 $\beta / T N F-\alpha$. The hemichannel activity was evaluated with the dye uptake method and was abrogated with selective inhibitors or knocking down of hemichannel protein subunits with siRNA. Western blot analysis, cell surface biotinylation, and confocal microscopy were used to evaluate total and plasma membrane amounts of specific proteins and their cellular distribution, respectively. Changes in intracellular $\mathrm{Ca}^{2+}$ and nitric oxide (NO) signals were estimated by measuring FURA-2 and DAF-FM probes, respectively. High glucose concentration was found to elevate

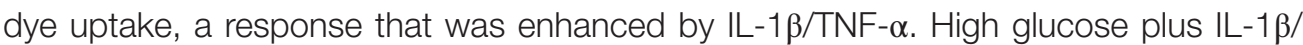
TNF- $\alpha$-induced dye uptake was abrogated by connexin 43 (Cx43) but not pannexin1 knockdown. Furthermore, Cx43 hemichannel activity was associated with enhanced ATP release and activation of $\mathrm{p} 38 \mathrm{MAPK}$, inducible $\mathrm{NO}$ synthase, $\mathrm{COX}_{2}, \mathrm{PGE}_{2}$ receptor $E P_{1}$, and $P 2 X_{7} / P 2 Y_{1}$ receptors. Inhibition of the above pathways prevented completely the increase in $\mathrm{Cx} 43$ hemichannel activity of cells treated high glucose and IL-1 $\beta / T N F-\alpha$. Both synthetic and endogenous cannabinoids (CBs) also prevented the increment in Cx43 hemichannel opening, as well as the subsequent generation and release of ATP and NO induced by pro-inflammatory conditions. The counteracting action of CBs also was extended to other endothelial alterations evoked by IL-1 $\beta / T N F-\alpha$ and high glucose, including increased ATP-dependent $\mathrm{Ca}^{2+}$ dynamics and insulin-induced $\mathrm{NO}$ production. Finally, inhibition of $\mathrm{C} \times 43$ hemichannels also prevented the ATP release from endothelial cells treated with IL-1 $1 \beta / T N F-\alpha$ and high glucose. Therefore, we propose that reduction of hemichannel activity could represent a strategy against the activation of deleterious pathways that lead to endothelial dysfunction and possibly cell damage evoked by high glucose and pro-inflammatory conditions during cardiovascular diseases.

Keywords: connexins, endothelium, inflammation, cytokines, gap junctions 


\section{INTRODUCTION}

The endothelial cell lining of vessels walls plays central roles in regulating vascular homeostasis, such as the maintenance of vessel integrity, supply of oxygen and nutrients to underlying tissues and promotion of a well-balanced redox and immune environment (1). Under physiological conditions, endothelial cells maintain a proper interface barrier between blood and tissue; surveilling and combating possible perturbations of invading pathogens or endogenous threats in response to tissue damage (2). The endothelium rapidly reacts to acute damage by modulating blood flow, permeability, leukocyte infiltration, and tissue edema (2). If the stimulus persists, chronic endothelial activation accompanied of sustained inflammation may lead to vascular dysfunction, precipitating macrophage recruitment, angiogenesis, and subsequent loss of vascular homeostasis (3). Chronic activation and dysfunction of endothelial cells are common features and part of the underlying origin of myocardial infarction, diabetes, stroke, obesity, unstable angina, metabolic syndrome, and sudden cardiac death (4). Although diverse conditions are present during these diseases, including high blood glucose levels, insulin resistance, oxidative stress, and upregulated cytokine production (5), the full underlying mechanisms associated with endothelial activation and dysfunction are not fully understood.

In the last decade, several studies have established that hemichannels mediate the physiological release of different signaling molecules (e.g., ATP, glutamate, $\mathrm{NAD}^{+}$, and $\mathrm{PGE}_{2}$ ) that preserve the progression of multiple biological processes, including long-term synaptic transmission (6), vessel contractility (7), and glucose sensing (8), among others. Hemichannels result from the oligomerization of six connexin monomers around a central pore, which along with forming the building blocks of gap junction channels, also acts as a solitary or non-junctional channels in the plasma membrane (9). Hemichannels are permeable to ions and small molecules; constituting routes of exchange between intracellular and extracellular compartments (10). Under certain pathophysiological scenarios, rather than being beneficial, the prolonged opening of hemichannels contributes to disease progression by different ways, including the enhanced release of paracrine substances (e.g., ATP and glutamate), intracellular $\mathrm{Ca}^{2+}$ handling alterations, and ionic and osmotic imbalance (11). A cornerstone underlying this phenomenon rise from the overproduction of inflammatory mediators as result of impaired operation of the innate and adaptive immune system (12).

There are plenty of data pointing out the detrimental effects of inflammation on endothelial function (2) and hyperglycemia is one of the most emblematic pro-inflammatory condition during different cardiovascular diseases $(13,14)$. Indeed, animal and clinical studies have shown that hyperglycemia causes the systemic production of pro-inflammatory cytokines such as TNF $\alpha$ and $\mathrm{IL}-1 \beta(15,16)$, as well as endothelial dysfunction (5). Among other changes, high glucose concentration in concert with proinflammatory cytokines alters numerous intracellular signaling pathways in endothelial cells $(17,18)$, which consequently lead to reduced endothelial barrier function, compromised vascular tone regulation and insulin resistance (5). Although prior evidence has described that IL-1 $\beta /$ TNF- $\alpha$ or high glucose $(25-45 \mathrm{mM})$ causes a prominent opening of hemichannels in diverse brain cell types $(8,19-23)$, whether high glucose concentration and/or pro-inflammatory cytokines can modulate hemichannel activity in endothelial cells remain poorly studied.

We hypothesize that high glucose concentration in combination IL- $1 \beta /$ TNF- $\alpha$ increase the hemichannel activity of endothelial cells, resulting in several cell alterations. Here, we show that high glucose concentration and IL- $1 \beta /$ TNF- $\alpha$ and increase the activity of endothelial connexin 43 ( $\mathrm{Cx} 43)$ hemichannels. Inhibition of these channels prevented the alterations of purinergic signaling, $\left[\mathrm{Ca}^{2+}\right]_{\mathrm{i}}$ signal dynamics, and nitric oxide (NO) production. Moreover, two endogenous cannabinoids (CBs): methanandamide (Meth) or 2-arachidonylglycerol (2-AG), as well as one synthetic CB: WIN 55,212-2 (WIN), prevent these events. In particular, they counteracted the persistent opening of endothelial Cx43 hemichannels mainly due to increase in the amount of $\mathrm{Cx} 43$ in the cell surface, which consequently prevented the manifestation of different endothelial alterations.

\section{MATERIALS AND METHODS}

\section{Reagents and Antibodies}

The mimetic peptides Gap19 (KQIEIKKFK, intracellular loop domain of Cx43), Tat-L2 (YGRKKRRQRRRDGANVDMHLK QIEIKKFKYGIEEHGK, second intracellular loop domain of Cx43), and ${ }^{10}$ panx1 [WRQAAFVDSY, first extracellular loop domain of pannexin1 (Panx1)] were obtained from Genscript (NJ, USA). HEPES, water (W3500), Dulbecco's Modified Eagle Medium (DMEM), A74003, MRS2179, brilliant blue G (BBG), oxidized ATP (oATP), ns-398, sc-19220, indometacin, L-N6, SB203580, Lucifer yellow (LY), Meth and 2-AG, WIN-55,212-2 (WIN), Cx43 polyclonal antibody, ethidium (Etd) bromide, and probenecid (Prob) were purchased from Sigma-Aldrich (St. Louis, MO, USA). Fetal bovine serum (FBS) was obtained from Hyclone (Logan, UT, USA). Penicillin, streptomycin, FURA2AM, DAF-FM diacetate, diamidino-2-phenylindole (DAPI), BAPTA-AM, goat anti-mouse Alexa Fluor 488 were obtained from Invitrogen (Carlsbad, CA, USA). The CB1 receptor antagonist (SR1): SR-141716A and the CB2 receptor antagonist (SR2): SR-144528 were kindly provided by Sanofi-Aventis Recherche (Bagneux, France). Normal goat serum (NGS) was purchased from Zymed (San Francisco, CA, USA). Anti-Cx43 monoclonal antibody (610061) was obtained from BD Biosciences (Franklin Lakes, NJ, USA). IL-1 $\beta$ and TNF- $\alpha$ were obtained from Roche Diagnostics (Indianapolis, MI, USA). Horseradish peroxidase (HRP)-conjugated anti-rabbit IgG, Sulfo-NHS-SS-biotin, and NeutrAvidin immobilized on agarose beads were purchased from Pierce (Rockford, IL, USA).

\section{Cell Cultures}

The human endothelial cell line EAhy 926 was kindly donated by Cora-Jean S. Edgell, University of North Carolina, Chapel Hill. ECs were seeded onto plastic dishes (Nunclon) or onto glass coverslips (Gassalem, Limeil-Brevannes, France) in DMEM, supplemented with penicillin $(5 \mathrm{U} / \mathrm{ml})$, streptomycin $(5 \mu \mathrm{g} / \mathrm{mL})$, and $10 \% \mathrm{FBS}$ and kept at $37^{\circ} \mathrm{C}$ in a $5 \% \mathrm{CO}_{2} / 95 \%$ air atmosphere 
at nearly $100 \%$ relative humidity. Passaging was performed at $\sim 90 \%$ confluence and cells were re-seeded at $1 \times 10^{4}$ cells $/ \mathrm{cm}^{2}$. Primary endothelial cells were isolated by collagenase $(0.25 \mathrm{mg} /$ $\mathrm{mL}$ ) digestion from umbilical cord veins (HUVEC) from normal pregnancies and cultured $\left(37^{\circ} \mathrm{C}, 5 \% \mathrm{CO}_{2}\right)$ up to passage 2 in medium 199 (M199) containing 10\% new born calf serum, 10\% fetal calf serum, $3.2 \mathrm{mM}$ L-glutamine, and $100 \mathrm{U} / \mathrm{mL}$ penicillinstreptomycin. Passaging was performed at $\sim 90 \%$ confluence and cells were re-seeded at $1 \times 10^{4}$ cells $/ \mathrm{cm}^{2}$.

\section{Treatments}

Cells were treated for $1,24,48$, or $72 \mathrm{~h}$ with a mixture of IL-1 $\beta$ and TNF- $\alpha$ (10 ng/mL of each) plus different concentrations of glucose $(5,25$, or $45 \mathrm{mM})$. Mimetic peptides against $\mathrm{Cx} 43$ hemichannels (gap19 and Tat-L2, $100 \mu \mathrm{M}$ ) and Panx1 channels $\left({ }^{10}\right.$ panx $\left.1,100 \mu \mathrm{M}\right)$, as well as Prob $(500 \mu \mathrm{M})$, were applied to cell cultures $15 \mathrm{~min}$ prior to and co-applied with Etd for time-lapse recordings (see below). CB agonists: WIN, Meth, and 2-AG were applied $1 \mathrm{~h}$ prior to and co-applied with the cytokines and glucose treatment. SR1 and SR2 antagonists were co-applied with the CB agonists. Similarly, in another set of experiments, SB203580 (p38 MAP kinase inhibitor), L-N6 [inducible NO synthase (iNOS) inhibitor], indomethacin $\left(\mathrm{COX}_{1}\right.$ and $\mathrm{COX}_{2}$ inhibitor), sc-560

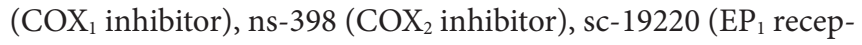
tor antagonist), BAPTA-AM (intracellular $\mathrm{Ca}^{2+}$ chelator), BBG (non-competitive $\mathrm{P}_{2} \mathrm{X}_{7}$ antagonist), oATP ( $\mathrm{P} 2 \mathrm{X}_{7}$ antagonist), MRS2179 (P2 $\mathrm{Y}_{1}$ antagonist), or A740003 (P2X $\mathrm{X}_{7}$ antagonist) were applied $1 \mathrm{~h}$ prior to and co-applied with IL- $1 \beta$ and TNF- $\alpha$ plus $25 \mathrm{mM}$ glucose for $72 \mathrm{~h}$.

\section{siRNA Transfection}

siRNA duplexes against mouse Cx43 or Panx1 were predesigned and obtained from Origene (Rockville, MD, USA). siRNA (10 nM) was transfected using Oligofectamine (Invitrogen) according to the Origene application guide for Trilencer-27 siRNA. Sequences for siRNAs against human $\mathrm{Cx} 43$ and Panx1 were siRNA-Cx43: rGrCrCrTrTrCrTrTrGrCrTrGrArTrCrCrArGrTrGrGrTrArCrATC and siRNA-Panx1: rGrArTrCrTrCrGrArTrTrGrGrTrArCrArCrArGrArTrArArGrCTG, respectively. Transfection experiment was performed $24 \mathrm{~h}$ before treating cells with IL-1 $\beta$ and TNF- $\alpha$ plus $25 \mathrm{mM}$ glucose for $72 \mathrm{~h}$.

\section{Dye Uptake and Time-Lapse Fluorescence Imaging}

For time-lapse fluorescence imaging, cells plated on glass coverslips were washed twice in Hank's balanced salt solution. Then, cells were incubated with Locke's solution containing $5 \mu \mathrm{M}$ Etd and mounted on the stage of an Olympus BX 51W1I upright microscope with a $40 \times$ water immersion objective for time-lapse imaging. Images were captured by a Retiga 1300I fast-cooled monochromatic digital camera (12-bit) (Qimaging, Burnaby, BC, Canada) controlled by imaging software Metafluor software (Universal Imaging, Downingtown, PA, USA) every $30 \mathrm{~s}$ (exposure time $=0.5 \mathrm{~s}$; excitation and emission wavelengths were 528 and $598 \mathrm{~nm}$, respectively). The fluorescence intensity recorded from 25 regions of interest (representing 25 cells per coverslip) was defined as the subtraction (F-F0) between the fluorescence (F) from respective cell (25 cells per field) and the background fluorescence (F0) measured where no labeled cells were detected. The mean slope of the relationship F-F0 over a given time interval $(\Delta \mathrm{F} / \Delta \mathrm{T}$; F0 remained constant along the recording time) represents the Etd uptake rate. To assess for changes in slope, regression lines were fitted to points before and after the various experimental conditions using Excel software, and mean values of slopes were compared using GraphPad Prism software and expressed as AU/min. At least four replicates (four sister coverslips) were measured in each independent experiment.

\section{Western Blot Analysis}

Cells were rinsed twice with PBS ( $\mathrm{pH} 7.4$ ) and harvested by scraping with a rubber policeman in ice-cold PBS containing $5 \mathrm{mM}$ EDTA, Halt (78440), and M-PER protein extraction cocktail (78501) according to the manufacturer instructions (Pierce, Rockford, IL, USA). The cell suspension was sonicated on ice. Proteins were measured using the Bio-Rad Bradford assay. Aliquots of cell lysates (100 $\mu \mathrm{g}$ of protein) were resuspended in Laemmli's sample buffer, separated in an $8 \%$ sodium dodecyl sulfate polyacrylamide gel electrophoresis (SDS-PAGE) and electro-transferred to nitrocellulose sheets. Nonspecific protein binding was blocked by incubation of nitrocellulose sheets in PBS-BLOTTO (5\% nonfat milk in PBS) for $30 \mathrm{~min}$. Blots were then incubated with primary antibody at $4^{\circ} \mathrm{C}$ overnight, followed by four $15 \mathrm{~min}$ washes with PBS. Then, blots were incubated with HRP-conjugated goat anti-rabbit antibody at room temperature for $1 \mathrm{~h}$ and then rinsed four times with PBS for $15 \mathrm{~min}$. Immunoreactivity was detected by enhanced chemiluminescence reaction using the SuperSignal kit (Pierce, Rockford, IL, USA) according to the manufacturer's instructions.

\section{Cell Surface Biotinylation and Quantification}

Cells cultured on 100-mm dishes were washed three times with ice-cold Hank's saline solution ( $\mathrm{pH} 8.0$ ), and $3 \mathrm{~mL}$ of sulfoNHS-SS-biotin solution $(0.5 \mathrm{mg} / \mathrm{mL})$ was added followed by a $30 \mathrm{~min}$ incubation at $4^{\circ} \mathrm{C}$. Then, cells were washed three times with ice-cold saline containing $15 \mathrm{mM}$ glycine ( $\mathrm{pH}$ 8.0) to block unreacted biotin. The cells were harvested and incubated with an excess of immobilized NeutrAvidin ( $1 \mathrm{~mL}$ of NeutrAvidin per $3 \mathrm{mg}$ of biotinylated protein) for $1 \mathrm{~h}$ at $4^{\circ} \mathrm{C}$ after which $1 \mathrm{~mL}$ of wash buffer (saline solution, $\mathrm{pH} 7.2$ containing $0.1 \%$ SDS and $1 \%$ Nonidet P-40) was added. The mixture was centrifuged for 2 min at $600 \mathrm{~g}$ at $4^{\circ} \mathrm{C}$. The supernatant was removed and discarded, and the pellet was resuspended in $40 \mu \mathrm{L}$ of saline solution, $\mathrm{pH} 2.8$ containing $0.1 \mathrm{M}$ glycine, to release the proteins from the biotin. After the mixture was centrifuged at $600 \mathrm{~g}$ at $4^{\circ} \mathrm{C}$ for $2 \mathrm{~min}$, the supernatant was collected, and the $\mathrm{pH}$ was adjusted immediately by adding $10 \mu \mathrm{L}$ of $1 \mathrm{M}$ Tris, $\mathrm{pH}$ 7.5. Relative protein amount was measured using Western blot analysis as described above. Resulting immunoblot signals were scanned, and the densitometric analysis was performed with IMAGEJ software. 


\section{Dye Coupling}

Cells plated on glass coverslips were bathed with recording medium ( $\mathrm{HCO}_{3}^{-}$free F-12 medium buffered with 10 mM HEPES, $\mathrm{pH}$ 7.2) and permeability mediated by gap junctions was tested by evaluating the transfer of LY to neighboring cells. Briefly, single ECs were iontophoretically microinjected with a glass micropipette filled with $75 \mathrm{mM} \mathrm{LY}(5 \% \mathrm{w} / \mathrm{v}$ in $150 \mathrm{mM} \mathrm{LiCl})$ in recording medium containing $200 \mu \mathrm{M} \mathrm{La}^{3+}$ to avoid cell leakage of the microinjected dye via hemichannels, leading to underscore the extent of dye coupling. Fluorescent cells were observed using a Nikon inverted microscope equipped with epifluorescence illumination (Xenon arc lamp) and Nikon B filter to LY (excitation wavelength $450-490 \mathrm{~nm}$; emission wavelength above $520 \mathrm{~nm}$ ) and XF34 filter to DiI fluorescence (Omega Optical, Inc., Brattleboro, VT, USA). Photomicrographs were obtained using a CCD monochrome camera (CFW-1310M; Scion; Frederick, MD, USA). Three minutes after dye injection, cells were observed to determine whether dye transfer occurred. The incidence of dye coupling was scored as the percentage of injections that resulted in dye transfer from the injected cell to more than one neighboring cell. Three experiments were performed for every treatment and dye coupling was tested by microinjecting a minimum of 10 cells per experiment.

\section{Immunofluorescence}

Cells grown on glass coverslips were fixed at room temperature with $2 \%$ paraformaldehyde for $30 \mathrm{~min}$ and then washed three times with PBS. Then, cells were incubated three times for $5 \mathrm{~min}$ in $0.1 \mathrm{M}$ PBS-glycine, followed by $30 \mathrm{~min}$ incubation with $0.1 \%$ PBS-Triton X-100 containing 10\% NGS. The permeabilized cells were incubated with anti- $\beta$-tubulin monoclonal antibody (Sigma, 1:400) and anti-Cx43 polyclonal antibody (SIGMA, 1:400) diluted in $0.1 \%$ PBS-Triton X-100 with $2 \% \mathrm{NGS}$ at $4^{\circ} \mathrm{C}$ overnight. After five rinses in $0.1 \%$ PBS-Triton $\mathrm{X}-100$, cells were incubated with goat anti-mouse IgG Alexa Fluor 555 (1:1,000), goat anti-rabbit IgG Alexa Fluor 488 (1:1,000), or Alexa Fluor 488-phalloidin at room temperature for $50 \mathrm{~min}$. After several rinses, coverslips were mounted in DAPI Fluoromount-G medium and examined with an Olympus BX 51W1I upright microscope with a $40 \times$ water immersion objective or a confocal laser-scanning microscope with a $63 \times$ objective (Olympus, Fluoview FV1000, Tokyo, Japan).

\section{Intracellular $\mathrm{Ca}^{2+}$ and $\mathrm{NO}$ Imaging}

Cells plated on glass coverslips were loaded with $5 \mu \mathrm{M}$ Fura2-AM or $5 \mu \mathrm{M}$ DAF-FM diacetate in DMEM without serum at $37^{\circ} \mathrm{C}$ for $45 \mathrm{~min}$ and then washed three times in Locke's solution (154 mM NaCl, $5.4 \mathrm{mM} \mathrm{KCl}, 2.3 \mathrm{mM} \mathrm{CaCl} 2,5 \mathrm{mM}$ HEPES, $\mathrm{pH}$ 7.4) followed by de-esterification at $37^{\circ} \mathrm{C}$ for $15 \mathrm{~min}$. The experimental protocol for $\mathrm{Ca}^{2+}$ signal and $\mathrm{NO}$ imaging involved data acquisition every $5 \mathrm{~s}$ (emission at 510 and $515 \mathrm{~nm}$, respectively) at 340/380-nm and 495 excitation wavelengths, respectively, using an Olympus BX 51W1I upright microscope with a $40 \times$ water immersion objective. Changes were monitored using an imaging system equipped with a Retga 1300I fast-cooled monochromatic digital camera (12-bit) (Qimaging, Burnaby, BC, Canada), monochromator for fluorophore excitation, and METAFLUOR software (Universal Imaging, Downingtown, PA, USA) for image acquisition and analysis. Analysis involved determination of pixels assigned to each cell. The average pixel value allocated to each cell was obtained with excitation at each wavelength and corrected for background. Due to the low excitation intensity, no bleaching was observed even when cells were illuminated for a few minutes. The FURA-2 ratio was obtained after dividing the $340-\mathrm{nm}$ by the $380-\mathrm{nm}$ fluorescence image on a pixel-by-pixel base $\left(R=F_{340 \mathrm{~nm}} / F_{380 \mathrm{~nm}}\right)$.

\section{Measurement of Extracellular ATP Concentration}

Cells were seeded $\left(2 \times 10^{6}\right.$ cells in $35 \mathrm{~mm}$ dishes $)$ in DMEM containing $10 \%$ FBS and treated with IL- $1 \beta$ and TNF- $\alpha$ plus $25 \mathrm{mM}$ glucose for $72 \mathrm{~h}$. Supernatants were collected, filtered $(0.22 \mu \mathrm{m})$, and stored at $-20^{\circ} \mathrm{C}$ before used for experiments. Then, extracellular ATP was measured using a luciferin/luciferase bioluminescence assay kit (Sigma-Aldrich). The amount of ATP in each sample was inferred from standard curves and normalized for the protein concentration as determined by the BCA assay (Pierce).

\section{Data Analysis and Statistics}

For each data group, results were expressed as mean \pm SEM; $n$ refers to the number of independent experiments. Detailed statistical results were included in the figure legends. Statistical analyses were performed using GraphPad Prism (version 7, GraphPad Software, La Jolla, CA, USA). Normality and equal variances were assessed by the Shapiro-Wilk normality test and Brown-Forsythe test, respectively. Unless otherwise stated, data that passed these tests were analyzed by unpaired $t$ test in case of comparing two groups, whereas in case of multiple comparisons, data were analyzed by one or two-way analysis of variance (ANOVA) followed, in case of significance, by a Tukey's post hoc test. A probability of $p<0.05$ was considered statistically significant.

\section{RESULTS}

\section{IL-1及/TNF- $\alpha$ Plus High Glucose Enhance the Activity of Cx43 Hemichannels in Endothelial Cells}

Previous studies have revealed that stimulation with IL-1 $\beta /$ TNF$\alpha$ or high glucose $(25-45 \mathrm{mM})$ causes a prominent opening of hemichannels in diverse brain cell types $(8,19-22)$. Given that inflammatory mediators play crucial roles in the activation of endothelial cells and because hemichannels may contribute to this process as they do in other tissues $(24,25)$, we examined whether two pro-inflammatory cytokines and high glucose could modulate the activity of these channels in the human endothelial cell line EAhy 926. The functional state of hemichannels was evaluated by measuring the rate of ethidium (Etd) uptake. Etd only move across the plasma membrane in normal cells by permeating specific large-pore channels such as hemichannels (26). After its binding to RNA and DNA, Etd becomes fluorescent, revealing channel opening when appropriate blockers are employed.

After incubation with $45 \mathrm{mM}$ but not $25 \mathrm{mM}$ glucose, EAhy cells exhibited a significant twofold increment in Etd uptake compared with physiological glucose concentration $(5 \mathrm{mM})$ 

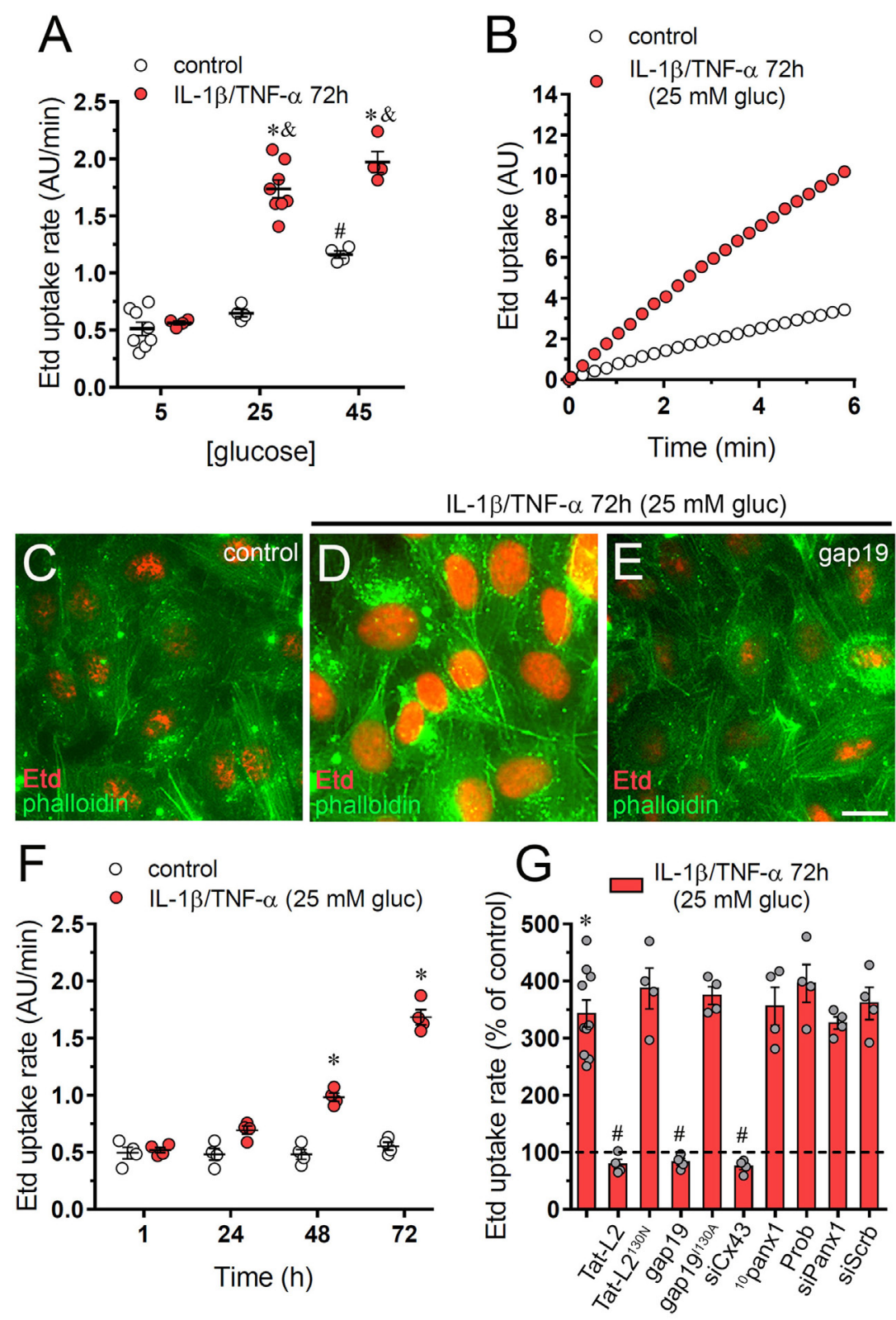

FIGURE 1 | High glucose and IL-1 $\beta$ plus TNF- $\alpha$ increase the activity of connexin 43 (Cx43) hemichannels in endothelial cells. (A) Averaged Etd uptake rate of EAhy cells treated for $72 \mathrm{~h}$ with different concentrations of glucose alone (control, white circles) or in combination with a mixture of IL-1 $\beta / \mathrm{TNF}-\alpha($ red circles; $10 \mathrm{ng} / \mathrm{mL}$ for

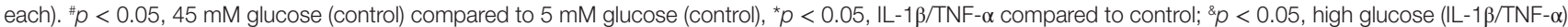
compared to $5 \mathrm{mM}$ glucose (IL-1 $\beta / \mathrm{TNF}-\alpha$ ) [two-way analysis of variance (ANOVA) followed by Tukey's post hoc test]. (B) Time-lapse measurements of Etd uptake by EAhy cells treated for $72 \mathrm{~h}$ with $5 \mathrm{mM}$ glucose (control, white circles) or $25 \mathrm{mM}$ glucose and IL-1 $\beta / \mathrm{TNF}-\alpha$ (red circles). (C-E) Representative immunofluorescence images depicting phalloidin-actin (green) and Etd-nucleus (red) staining from dye uptake measurements (10 min exposure to dye) in EAhy cells treated for $72 \mathrm{~h}$ with $5 \mathrm{mM}$ glucose [control (C)], $25 \mathrm{mM}$ glucose and IL-1 $\beta / T N F-\alpha(\mathbf{D})$ alone or plus $100 \mu \mathrm{M}$ gap19. (F) Averaged Etd uptake rate by EAhy cells treated for several time periods with $5 \mathrm{mM}$ glucose (control, white circles) or $25 \mathrm{mM}$ glucose and IL-1 $\beta / \mathrm{TNF}-\alpha$ (red circles). ${ }^{*} p<0.05$, IL-1 $\beta / \mathrm{TNF}-\alpha$ and high glucose compared to control (two-way ANOVA followed by Tukey's post hoc test). (G) Averaged Etd uptake rate normalized with control condition (dashed line) by EAhy cells treated for $72 \mathrm{~h}$ with

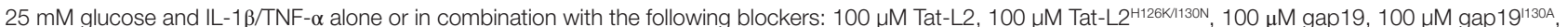

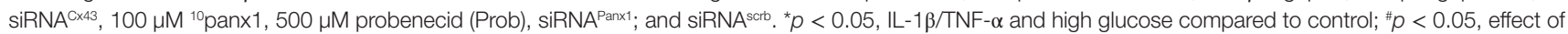
blockers compared IL-1 $\beta / \mathrm{TNF}-\alpha$ and high glucose (one-way ANOVA followed by Tukey's post hoc test). Data were obtained from at least three independent experiments (see scatter dot plot) with four repeats each one ( $\geq 35$ cells analyzed for each repeat). Calibration bar $=20 \mu \mathrm{m}$.

(Figure 1A). Relevantly, a combination of IL-1 $\beta$ and TNF- $\alpha$ (10 ng/mL of each) enhanced the response evoked by $45 \mathrm{mM}$ glucose (Figure 1A), whereas $25 \mathrm{mM}$ glucose (hereinafter referred as to "high glucose") only increased Etd uptake when applied in combination with IL-1 $\beta /$ TNF- $\alpha$ (Figures 1A-D). Moreover, IL- $1 \beta /$ TNF- $\alpha$ and high glucose triggered a time-dependent 
proportional rise in Etd uptake, being $72 \mathrm{~h}$ of treatment the most significant as it evoked a 3.5-fold augment in relation to control treatment (Figure 1F). No changes in Etd uptake were observed upon treatment with IL-1 $\beta /$ TNF- $\alpha$ and plus high sucrose or high mannitol excluding the possibility of an osmolarity-mediated response (Figure S1A in Supplementary Material).

Endothelial cells express functional Cx43 hemichannels (2729) and Panx1 channels $(30,31)$. Pannexins encompass a threemember protein family that constitute unopposed membrane channels referred as pannexons that-just like hemichannelsallow paracrine/autocrine communication in cellular tissues (32). The involvement of $\mathrm{Cx} 43$ hemichannels in IL- $1 \beta / \mathrm{TNF}-\alpha$ and high glucose-mediated Etd uptake was examined employing specific mimetic peptides (Tat-L2 and gap19) with sequences homologous to intracellular L2 loop domains of Cx43 $(33,34)$. Cells treated with IL-1 $\beta /$ TNF- $\alpha$ and high glucose for $72 \mathrm{~h}$ and incubated for $15 \mathrm{~min}$ of incubation with Tat-L2 $(100 \mu \mathrm{M})$ or gap19 $(100 \mu \mathrm{M})$ before and during the dye uptake evaluation showed an Etd uptake close to that of control cells (Figures 1C,E,G). In addition, a mutated TAT-L2 $\left(200 \mu \mathrm{M}\right.$ TAT-L2 $\left.2^{\mathrm{H} 126 \mathrm{~K} / 1130 \mathrm{~N}}\right)$, in which 2 aa crucial for interaction of L2 domain to the carboxyl tail of $\mathrm{Cx} 43$ are modified, was unsuccessful in trigger a comparable inhibition (Figure 1G). Likewise, we noticed that an inactive form of gap19 containing the I130A modification (gap19 ${ }^{\mathrm{I130A}}$ ), did not inhibit the IL- $1 \beta /$ TNF- $\alpha$ and high glucose-induced Etd uptake in EAhy cells (Figure 1G). Consistent with these findings, knockdown of Cx43 with siRNA fully abolished the Etd uptake caused by IL-1 $\beta$ / TNF- $\alpha$ and high glucose (Figure 1G). Conversely, scrambled siRNA, siRNA for Panx1, the Panx1 mimetic peptide ${ }^{10}$ panx1 $(100 \mu \mathrm{M})$, or probenecid $(200 \mu \mathrm{M})$ failed to cause a similar suppression (Figure 1G). These results strongly bring up that IL-1 $\beta$ / TNF- $\alpha$ and high glucose significantly increase the activity of $\mathrm{Cx} 43$ hemichannels, but not Panx1 channels in EAhy endothelial cells.

\section{Endothelial Cx43 Hemichannel Activity Induced by IL-1 $\beta /$ TNF- $\alpha$ Plus High Glucose Depends on p38 MAP Kinase/iNOS/COX $/$ $E P_{1}$ and Purinergic Pathways}

During inflammatory conditions, endothelial cells display a strong stimulation of the iNOS and cyclooxygenase $2\left(\mathrm{COX}_{2}\right)(35$, 36 ), two enzymes that generate byproducts (NO and prostaglandins, respectively) associated with $\mathrm{Cx} 43$ hemichannel activation (37-39). In addition, prior research has unveiled the participation of p38 MAP kinase (p38 MAPK) in both the opening of $\mathrm{Cx} 43$ hemichannels (20) and inflammatory activation of endothelial cells $(40,41)$. Accordingly, we examined the influence of p38 MAPK, iNOS, and $\mathrm{COX}_{2}$ pathways on the IL-1 $\beta /$ TNF- $\alpha$ and high glucose-induced Etd uptake in EAhy cells. The Etd uptake triggered by IL- $1 \beta /$ TNF- $\alpha$ and high glucose treatment for $72 \mathrm{~h}$ was greatly reduced by blockade of p38 MAPK with SB202190 $(10 \mu \mathrm{M})$ or inhibition of iNOS with L-N6 $(5 \mu \mathrm{M})$ (Figure 2A). Notably, COX inhibition by indomethacin $(15 \mu \mathrm{M})$ reduced the $\sim 3.5$-fold increase on Etd uptake evoked by IL-1 $\beta /$ TNF- $\alpha$ and high glucose to control conditions (Figure 2A). To investigate which COX was implicated in the above effect, we used sc-560 and ns-398, specific inhibitors for $\mathrm{COX}_{1}$ and $\mathrm{COX}_{2}$, respectively.

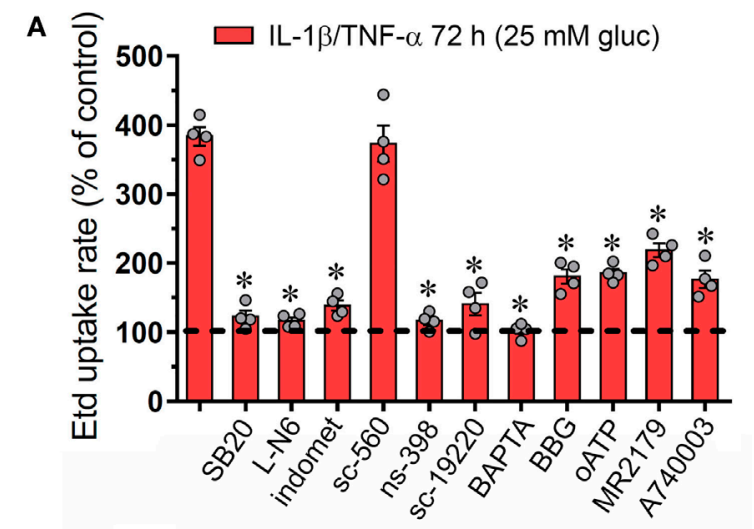

B

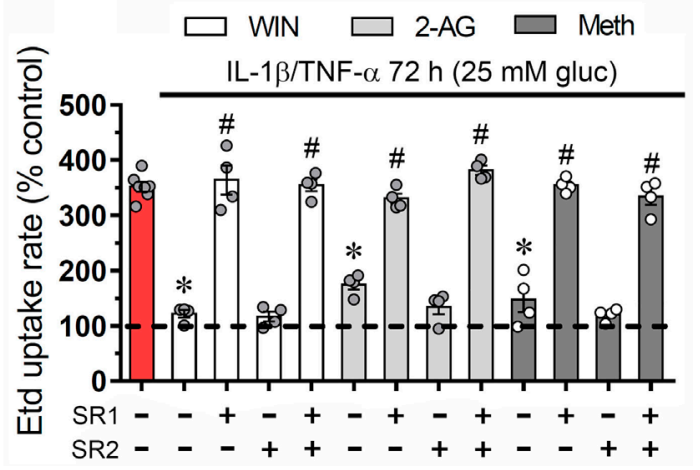

FIGURE 2 | Endothelial connexin 43 (Cx43) hemichannel opening evoked by high glucose and IL-1 $\beta / \mathrm{TNF}-\alpha$ depends on $\mathrm{Ca}^{2+}$ signaling and activation of p38 MAPK/inducible NO synthase/COX ${ }_{2}$-dependent pathways and $\mathrm{EP}_{1} / \mathrm{P} 2$ receptors: prevention by cannabinoids. (A) Averaged Etd uptake rate normalized with control conditions ( $5 \mathrm{mM}$ glucose, dashed line) of EAhy cells treated for $72 \mathrm{~h}$ with $25 \mathrm{mM}$ glucose and IL-1 $\beta / \mathrm{TNF}-\alpha$ alone or in combination with the following agents: $10 \mu \mathrm{M}$ SB203580, $1 \mu \mathrm{M} \mathrm{L-N6}, 15 \mu \mathrm{M}$ indometacin (indomet); $1 \mu \mathrm{M}$ sc-560; $5 \mu \mathrm{M}$ ns-398; $20 \mu \mathrm{M}$ sc-19220, $10 \mu \mathrm{M}$ BAPTA, $10 \mu \mathrm{M}$ Brilliant blue G (BBG), $200 \mu \mathrm{M}$ oxidized ATP (OATP), $10 \mu \mathrm{M}$ MRS2179; and $10 \mu \mathrm{M}$ A740003. ${ }^{*} p<0.05$, effect of blockers compared to IL- $1 \beta / T N F-\alpha$ and high glucose [one-way analysis of variance (ANOVA) followed by Tukey's post hoc test]. (B) Averaged Etd uptake rate normalized with control conditions ( $5 \mathrm{mM}$ glucose, dashed line) by EAhy cells treated for $72 \mathrm{~h}$ with $25 \mathrm{mM}$ glucose and IL-1 $\beta / \mathrm{TNF}-\alpha$ (red bar) alone or in combination with the following cannabinoids: WIN (5 $\mathrm{MM}$, white bars), 2-arachidonylglycerol (5 $\mu \mathrm{M}$, light gray bars), and Meth ( $5 \mu \mathrm{M}$, dark gray bars). It is also shown the effect of the respective cannabinoid co-treatment with the $\mathrm{CB}_{1}$ or $\mathrm{CB}_{2}$ receptor antagonist, SR-141716A (5 $\mu \mathrm{M})$ and/or SR-144528 (5 $\mu \mathrm{M})$, respectively. ${ }^{*} p<0.05$, effect of each cannabinoid compared to the effect induced by $72 \mathrm{~h}$ treatment with IL-1 $\beta / \mathrm{TNF}-\alpha$ and high glucose; $\# p<0.05$, effect of each cannabinoid receptor antagonist compared to the effect of the respective cannabinoid (one-way ANOVA followed by Tukey's post hoc test). Data were obtained from at least three independent experiments (see scatter dot plot) with four repeats each one ( $\geq 35$ cells analyzed for each repeat).

sc-560 $(1 \mu \mathrm{M})$ failed in neutralizing the Etd uptake caused by IL-1 $\beta /$ TNF- $\alpha$ and high glucose, whereas ns-398 (5 $\mu \mathrm{M})$ completely abolished it (Figure 2A).

Previous findings indicate that $\mathrm{NO}$ elevates $\mathrm{COX}_{2}$ activity and prostaglandin $\mathrm{E}_{2}\left(\mathrm{PEG}_{2}\right)$ generation in macrophages (42) and a similar phenomenon seems to occur in inflamed endothelial cells (43). Given that activation of $\mathrm{PEG}_{2}$ receptor $1\left(\mathrm{EP}_{1}\right)$ lead to increases in $\left[\mathrm{Ca}^{2+}\right]_{\mathrm{i}}(44)$ and the latter is a well-known mechanism 
that increase the open probability of $\mathrm{Cx} 43$ hemichannels (45), we examined if this signaling is involved in the IL- $1 \beta /$ TNF- $\alpha$ and high glucose-mediated Etd uptake in EAhy cells. Blockade of $\mathrm{EP}_{1}$ receptor with sc-19220 $(20 \mu \mathrm{M})$ was found to diminish the Etd uptake caused by IL-1 $\beta /$ TNF- $\alpha$ and high glucose, whereas $5 \mu \mathrm{M}$ BAPTA-AM, a $\mathrm{Ca}^{2+}$ chelator, caused a similar inhibition (Figure 2A). The opening of $\mathrm{Cx} 43$ hemichannels has been correlated with $\left[\mathrm{Ca}^{2+}\right]_{i}$-mediated purinergic signaling $(46,47)$, thereby, we tested if purinergic receptors participate in the IL-1 $\beta$ / TNF- $\alpha$ and high glucose-induced Etd uptake in EAhy cells. Remarkably, $200 \mu \mathrm{M}$ oATP, a general P2X receptor blocker, or $10 \mu \mathrm{M}$ A740003 and $10 \mu \mathrm{M}$ BBG, both $\mathrm{P}_{2} \mathrm{X}_{7}$ receptor inhibitors, partially antagonized the Etd uptake induced by IL- $1 \beta /$ TNF- $\alpha$ and high glucose (Figure 2A). Similarly, the blockade of $\mathrm{P} 2 \mathrm{Y}_{1}$ receptors with $10 \mu \mathrm{M}$ MRS2179 evoked a partial but significant reduction in the IL- $1 \beta / \mathrm{TNF}-\alpha$ and high glucose-induced Etd uptake. All these data suggest that endothelial Cx43 hemichannel activity triggered by IL- $1 \beta /$ TNF- $\alpha$ and high glucose rely on the stimulation of $\mathrm{p} 38 \mathrm{MAPK} / \mathrm{iNOS} / \mathrm{COX}_{2} / \mathrm{EP}_{1}$-dependent pathway(s) and the $\mathrm{P} 2 \mathrm{X}_{7} / \mathrm{P} 2 \mathrm{Y}_{1}$ receptor-mediated changes in cytoplasmic $\mathrm{Ca}^{2+}$ signal.

\section{CBs Counteract the Opening of Cx43 Hemichannels Induced by IL-1 $\beta / T N F-\alpha$ Plus High Glucose in Endothelial Cells}

An unresolved topic in the field of hemichannels is to recognize compounds that could prevent their increased opening during pathological conditions. Possible aspirants for this intent are CBs, as they successfully prevent the persistent $\mathrm{Cx} 43$ hemichannel opening triggered by different inflammatory conditions in glial cells (48-50). Whether plant-derived, synthetic, or endocannabinoids, $\mathrm{CBs}$ are biolipid molecules that activate at least two $\mathrm{CB}$ receptors: $\mathrm{CB}_{1}$ and $\mathrm{CB}_{2}$ (51). Because endothelial cells express $\mathrm{CB}_{1} / \mathrm{CB}_{2}$ receptors (52) and $\mathrm{CBs}$ elicit anti-inflammatory defense facing cytokine-dependent endothelial dysfunction (53), we examined whether CBs could ameliorate the increase in $\mathrm{Cx} 43$ hemichannel activity evoked by IL- $1 \beta / \mathrm{TNF}-\alpha$ and high glucose in EAhy cells.

To elucidate whether CBs could regulate the Cx43 hemichannel activity in EAhy cells, we pre-incubated the cells with synthetic and endogenous CBs for $1 \mathrm{~h}$ and then were co-applied for $72 \mathrm{~h}$ along with IL-1 $\beta /$ TNF- $\alpha$ and high glucose. WIN-55,212-2 (WIN; $5 \mu \mathrm{M}$ ), a synthetic agonist of $\mathrm{CB}_{1} / \mathrm{CB}_{2}$ receptors, completely blunted the IL-1 $\beta /$ TNF- $\alpha$ and high glucose-induced Etd uptake in EAhy cells since these cells showed an Etd uptake comparable to control values (Figure 2B). Furthermore, we used two endogenous $\mathrm{CB}_{1} / \mathrm{CB}_{2}$ receptor agonists: $2-\mathrm{AG}$ and methanandamide (Meth), the latter being a synthetic analog of the endocannabinoid anandamide. We observed that $5 \mu \mathrm{M} 2$-AG and $5 \mu \mathrm{M}$ Meth reduced the increase in Etd uptake rate of EAhy cells caused by the IL-1 $\beta /$ TNF- $\alpha$ and high glucose treatment to $\sim 169$ and $\sim 146 \%$, respectively (Figure $2 \mathrm{~B}$ ). $\mathrm{CB}_{1}$ and $\mathrm{CB}_{2}$ receptor antagonists, SR-141716 (SR1) and SR-144528 (SR2), respectively, were employed to characterize the sub-type of CB receptor implicated in the counteracting response on Etd uptake evoked by IL-1 $\beta$ / TNF- $\alpha$ and high glucose (Figure 2B). With the application of
$10 \mu \mathrm{M}$ SR1 antagonist, WIN, 2-AG, and Meth failed in preventing the IL- $1 \beta /$ TNF- $\alpha$ and high glucose-mediated Etd uptake in EAhy cells, whereas $10 \mu \mathrm{M}$ SR2 was ineffective in evoke a comparable preventing effect (Figure 2B). These findings indicate that $\mathrm{CB}_{1}$, but not $\mathrm{CB}_{2}$ receptors are the major contributors to the WIN, 2-AG, and Meth counteracting responses of the IL- $1 \beta / \mathrm{TNF}-\alpha$ and high glucose-evoked Cx43 hemichannel activity in endothelial cells.

\section{WIN Counteract the Increment in Cx43 Surface Amount and Gap Junctional Uncoupling Triggered by IL-1 $\beta / T N F-\alpha$ Plus High Glucose in Endothelial Cells}

Connexin 43 hemichannel activity could depend on increments in both the open probability per channel and/or the number of channels at the cell surface. Previous studies have correlated the hemichannel-dependent Etd uptake with elevated surface levels of $\mathrm{Cx} 43$ in different cell types $(8,39,50)$ or increase in open probability without changes in the total amount of $\mathrm{Cx} 43$ in the cell surface (54). Here, we evaluated if the counteracting effect of CBs on IL- $1 \beta /$ TNF- $\alpha$ and high glucose-mediated hemichannel activity depend on changes in surface amount of Cx43. IL-1 $\beta$ / TNF- $\alpha$ and high glucose caused a slight but significant $\sim 30 \%$ decrease in total $\mathrm{Cx} 43$ compared to control conditions, a response fully suppressed by $5 \mu \mathrm{M}$ WIN (Figures 3A,B). Moreover, IL-1 $\beta$ / TNF- $\alpha$ and high glucose also evoked a $\sim 1$.7-fold rise in surface amount of Cx43 and experiments with WIN fully blunted this effect (Figures 3A,B). Therefore, the ameliorative effects of CBs on IL- $1 \beta /$ TNF- $\alpha$ and high glucose-induced $\mathrm{Cx} 43$ hemichannel
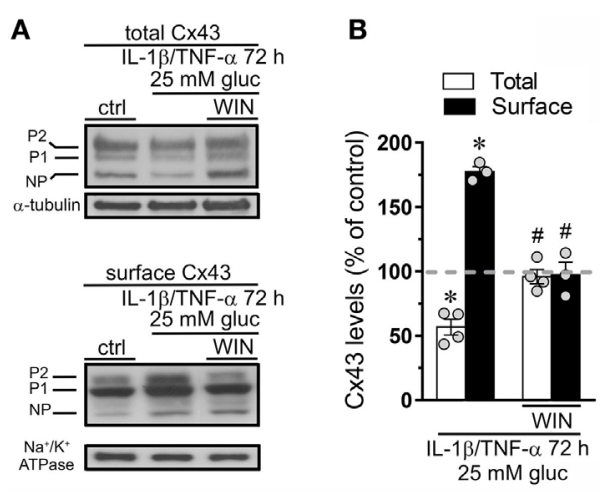

FIGURE 3 | WIN counteracts the increase in surface levels of connexin 43 (Cx43) induced by high glucose and IL-1 $\beta / \mathrm{TNF}-\alpha$ in endothelial cells. (A) Total (upper panel) and surface (bottom panel) levels of Cx43 by EAhy cells treated for $72 \mathrm{~h}$ with $5 \mathrm{mM}$ glucose (control), $25 \mathrm{mM}$ glucose, and IL-1 $\beta / \mathrm{TNF}-\alpha$ alone or in combination with $5 \mu \mathrm{M}$ WIN. The $\mathrm{C} \times 43$ phosphorylated (P1-P2) and nonphosphorylated (NP) forms are indicated in the left. Total and surface amount of each analyzed band were normalized according to the amount of $\alpha$-tubulin and $\mathrm{Na}^{+} / \mathrm{K}^{+}$ATPase detected in each lane, respectively. (B) Quantification of total (white bars) and surface (black bars) amount of Cx43 normalized to control (dashed line) in EAhy cells harvested $72 \mathrm{~h}$ after treatment with $25 \mathrm{mM}$ glucose and IL-1 $\beta / \mathrm{TNF}-\alpha$ alone or in combination with $5 \mu \mathrm{M}$ WIN. ${ }^{*} p<0.05$, $\mathrm{IL}-1 \beta / \mathrm{TNF}-\alpha$ and high glucose compared to control; ${ }^{*} p<0.05$, effect of each cannabinoid compared to the effect induced by IL-1 $\beta / \mathrm{TNF}-\alpha$ and high glucose (two-tailed Student's unpaired $t$-test). Averaged data were obtained from at least three independent experiments (see scatter dot plot). 
activity may take place because they interfere with the increment in surface amount of $\mathrm{Cx} 43$.

Endothelial-to-endothelial gap junctional communication is critical for the endothelium-derived hyperpolarization and concomitant vasodilation of the arteriolar smooth muscle (55). Given that increased Cx43 hemichannel opening induced by inflammatory conditions has been described to occur along with a rise in endothelial dye coupling (27), we evaluated if the endothelial gap junction coupling was altered upon treatment with IL- $1 \beta / \mathrm{TNF}-\alpha$ and high glucose. Under control conditions around $\sim 80 \%$ of EAhy cells exhibited LY intercellular diffusion to neighboring cells (Figures 4A,D,G). Nonetheless, $72 \mathrm{~h}$ after treatment with IL-1 $\beta /$ TNF- $\alpha$ and high glucose intercellular dye transfer decreased by $\sim 38 \%$ compared with control levels
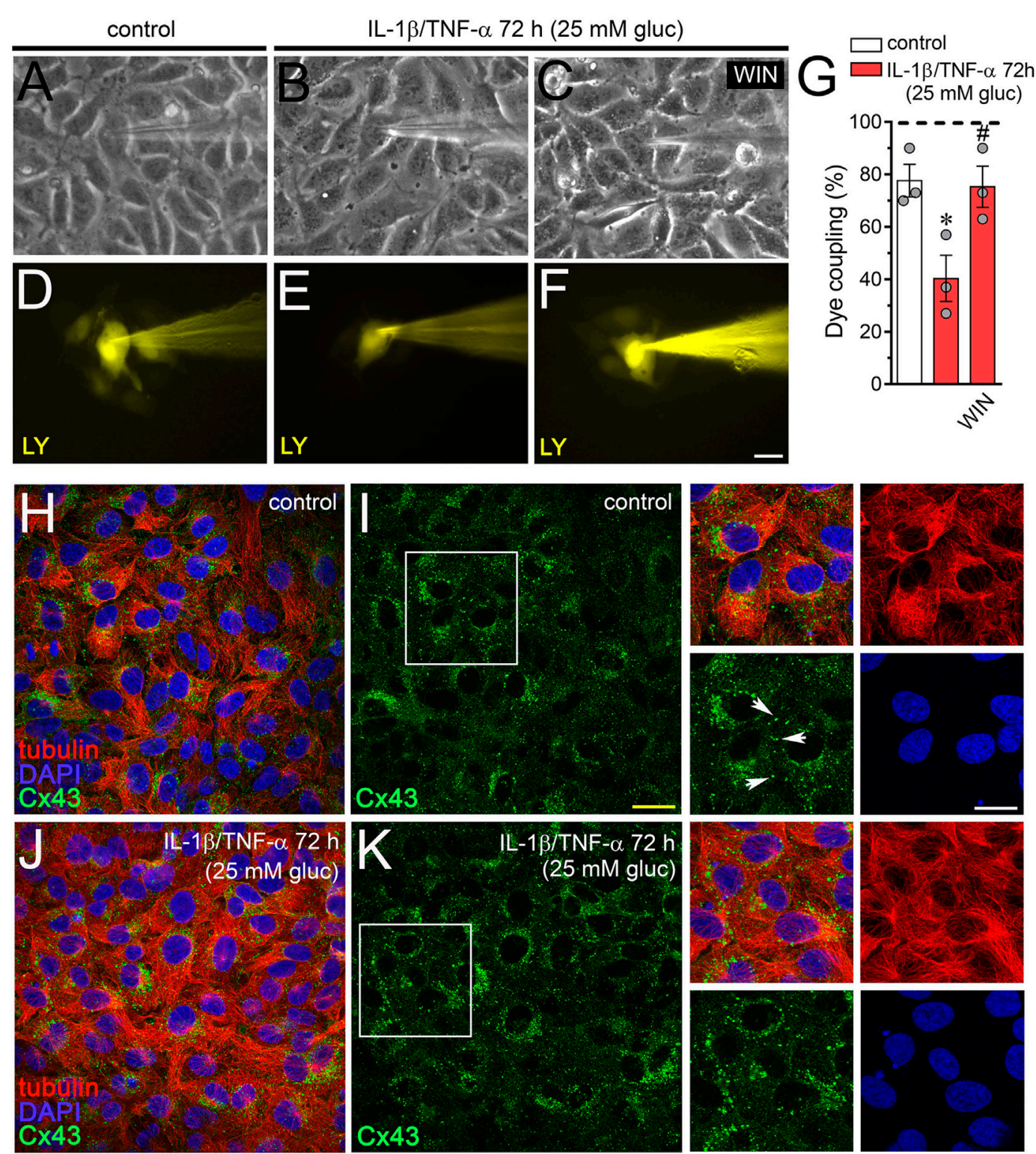

FIGURE 4 | WIN prevents the high glucose and IL-1 $\beta / T N F-\alpha$-induced decrease in endothelial coupling through a mechanism that does not involve changes in connexin 43 (Cx43) distribution. (A-F) Representative fluorescence and phase contrast micrographs of Lucifer yellow (LY) transfer by EAhy cells treated for $72 \mathrm{~h}$ with

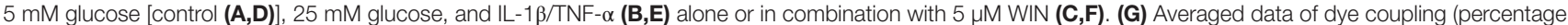

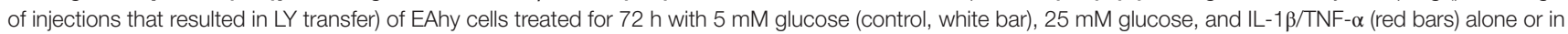
combination with $5 \mu \mathrm{M}$ WIN. ${ }^{*} p<0.05$, IL-1 $\beta / T N F-\alpha$ and high glucose compared to control; ${ }^{*} p<0.05$, effect of each cannabinoid compared to the effect induced by IL-1 $\beta / T N F-\alpha$ and high glucose (one-way analysis of variance followed by Dunnett's post hoc test). Data were obtained from at least three independent experiments (see scatter dot plot) with four repeats each one ( $\geq 10$ cells analyzed for each repeat). (H-K) Representative fluorescence images depicting $\mathrm{Cx} 43$ (green), tubulin (red), and DAPI (blue) immunolabeling of EAhy cells treated for $72 \mathrm{~h}$ with $5 \mathrm{mM}$ glucose [control (H,I)] and $25 \mathrm{mM}$ glucose plus IL-1 $1 \beta / T N F-\alpha(\mathbf{J}, \mathbf{K})$ Insets: $1.7 \times$ magnification of the indicated area of panels $\mathbf{( I , K )}$. White arrows indicate $\mathrm{C} \times 43$ labeling in cell-cell interfaces. Calibration bars: white $=35 \mu \mathrm{m}$, yellow $=60 \mu \mathrm{m}$, and green $=25 \mu \mathrm{m}$. 
(Figures 4B,E,G). Equivalently, to the counteracting influence on IL-1 $\beta /$ TNF- $\alpha$ and high glucose-evoked Etd uptake, WIN entirely prevented the reduction in endothelial cell-cell coupling induced by IL- $1 \beta /$ TNF- $\alpha$ and high glucose (Figures 4 C,F,G). Given that endocytosis of gap junctions from the plasma membrane is a process that might cause cellular uncoupling, we explored if IL- $1 \beta /$ TNF- $\alpha$ and high glucose-induced endothelial uncoupling was correlated with alterations in the cellular distribution of Cx43. In control EAhy cells, Cx43 was observed as fine to large granules scattered at cellular interfaces and perinuclear regions (Figures $4 \mathbf{H}, \mathbf{I}$ ) and comparable features were detected in those treated with IL-1 $\beta /$ TNF- $\alpha$ and high glucose (Figures 4 J,K) or plus $5 \mu \mathrm{M}$ WIN (Figures S1B-D in Supplementary Material). These findings indicate that IL- $1 \beta / \mathrm{TNF}-\alpha$ and high glucose-induced cell-to-cell uncoupling may depend on a mechanism implicating the closure and/or decreased permeability of $\mathrm{Cx} 43$ gap junctions rather than withdrawal from the apposition membranes.

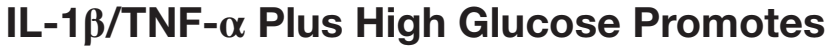 the Cx43 Hemichannel-Induced Release of ATP From Endothelial Cells: Counteracting Action by WIN}

Endothelial cells subjected to inflammatory conditions exhibit elevated release of ATP via the opening of Cx43 hemichannels $(27,56)$, a major signal involved in leukocyte recruitment and vascular inflammation (57). Given that $\mathrm{P}_{2} \mathrm{X}_{7}$ and $\mathrm{P}_{2} \mathrm{Y}_{1}$ receptors are involved in the Etd uptake evoked by IL- $1 \beta /$ TNF- $\alpha$ and high glucose in EAhy cells (Figure 2A), we evaluated whether this treatment could also impact the release of ATP via Cx43 hemichannels. IL-1 $\beta / \mathrm{TNF}-\alpha$ and high glucose strongly enhanced the release of ATP by $\sim 6$-folds compared to control conditions (Figure 5). Importantly, gap19 and Tat-L2, but not ${ }^{10}$ panx 1 or probenecid, prominently reduced to control values the extracellular ATP concentration of cells treated with IL-1 $\beta$ / TNF- $\alpha$ and high glucose-induced release of ATP (from $\sim 68$ to $\sim 13$ and $\sim 12 \mathrm{pmol} / 10^{6}$ cells, respectively) (Figure 5). These findings indicate that IL- $1 \beta / \mathrm{TNF}-\alpha$ and high glucose elevate the release of ATP in a $\mathrm{Cx} 43$ hemichannel-dependent form in EAhy endothelail cells. In this context, we tested the probable counteracting influence of WIN on this response. We observed that $1 \mathrm{~h}$ pretreatment and co-incubation with $5 \mu \mathrm{M}$ WIN drastically reduced the IL- $1 \beta / \mathrm{TNF}-\alpha$ and high glucose-mediated release of ATP (from $\sim 68$ to $\sim 11 \mathrm{pmol} / 10^{6}$ cells) (Figure 5). Interestingly, WIN failed in decreasing the ATP release in EAhy cells pre-incubated with $10 \mu \mathrm{M}$ SR 1 antagonist. Altogether, these findings support that $\mathrm{CB}_{1}$ receptors are the main contributors to the WIN-mediated inhibition of $\mathrm{Cx} 43$ hemichannel-dependent release of ATP evoked by IL-1 $\beta /$ TNF- $\alpha$ and high glucose in endothelial cells.

\section{IL-1 $\beta / T N F-\alpha$ and High Glucose-Induced Changes in ATP-Dependent $\mathrm{Ca}^{2+}$ Dynamics Are Prevented by WIN in Endothelial Cells}

Although cytoplasmic $\mathrm{Ca}^{2+}$ is crucial for proper endothelial barrier permeability and remodeling, its abnormal signaling

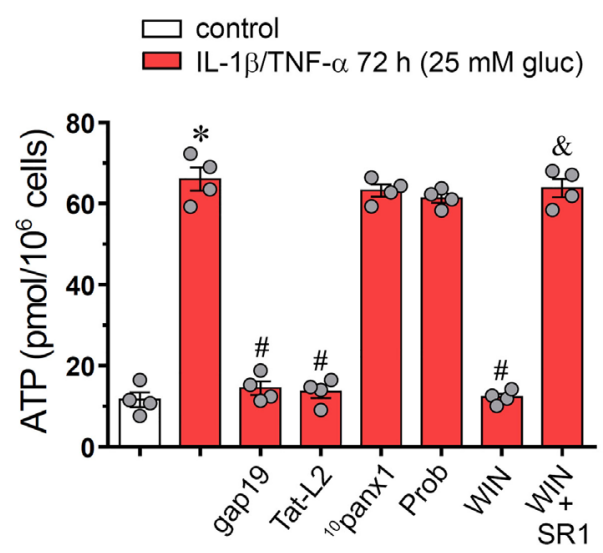

FIGURE 5 | WIN mitigates the connexin 43 (Cx43) hemichannel-dependent release of ATP evoked by high glucose and IL-1 $\beta / T N F-\alpha$ in endothelial cells. Averaged data of ATP release from EAhy cells treated for $72 \mathrm{~h}$ with $5 \mathrm{mM}$ glucose (control, white bar), $25 \mathrm{mM}$ glucose, and IL-1 $\beta / \mathrm{TNF}-\alpha$ (black bars) alone or in combination with the following agents: $100 \mu \mathrm{M}$ gap $19,100 \mu \mathrm{M}$ Tat-L2, $100 \mu \mathrm{M}{ }^{10}$ panx1, $500 \mu \mathrm{M}$ probenecid (Prob), $5 \mu \mathrm{M}$, WIN and/or $5 \mu \mathrm{M}$ SR-141716A (SR1). ${ }^{*} p<0.05, \mathrm{IL}-1 \beta / \mathrm{TNF}-\alpha$ and high glucose compared to control; $" p<0.05$, effect of each agent compared to the effect induced by IL-1 $\beta /$ TNF- $\alpha$ and high glucose; ${ }^{\&} p<0.05$, effect of each cannabinoid receptor antagonist compared to the effect of the respective cannabinoid (one-way analysis of variance followed by Tukey's post hoc test). Data were obtained from at least three independent experiments (see scatter dot plot) with four repeats each one.

during inflammatory conditions could lead to multiple vascular diseases $(58,59)$. Relevantly, both endothelial $\left[\mathrm{Ca}^{2+}\right]$ signaling and hemichannel functional state are interdependent processes that may be enhanced during pathological conditions (60). In this context and because intracellular BAPTA greatly blunted IL-1 $\beta$ / TNF- $\alpha$ and high glucose-mediated Etd uptake (Figure 1A), we investigated if this condition could modulate the basal $\mathrm{Ca}^{2+}$ signal in EAhy cells. As indicated by the assessment of Fura- 2 ratio (340/380), IL-1 $\beta /$ TNF- $\alpha$ and high glucose-stimulated EAhy cells showed basal $\mathrm{Ca}^{2+}$ signal that was similar to control conditions (Figures 6A,C,K). Despite that IL-1 $\beta / \mathrm{TNF}-\alpha$ and high glucose fail in modulate basal $\mathrm{Ca}^{2+}$ signal, these data do not rule out whether this condition affects the $\mathrm{Ca}^{2+}$ signal responses evoked by autocrine/paracrine signals, including ATP. With this in mind, we also studied the impact of IL- $1 \beta /$ TNF- $\alpha$ and high glucose on ATP-mediated $\mathrm{Ca}^{2+}$ signaling, as this transmitter can be released through Cx43 hemichannels from EAhy cells (Figure 6). Under control conditions, treatment with $500 \mu \mathrm{MATP}$ caused a rapid $\mathrm{Ca}^{2+}$ signal response with a small peak amplitude (Figures 6A,B,E,L). However, high glucose induced a sustained ATP-dependent $\mathrm{Ca}^{2+}$ signal response with a peak amplitude $\sim 4$-fold higher than that of control conditions (Figures 6C,D,F,L). This phenomenon was accompanied of a $\sim 4$ - and $\sim 4$.5-fold increment in the integrated ATP-dependent $\mathrm{Ca}^{2+}$ signal response (Figure 6M) and the remaining difference between final and initial basal $\mathrm{Ca}^{2+}$ signal (Figure 6N), respectively.

In endothelial cells, ATP-mediated $\left[\mathrm{Ca}^{2+}\right]_{\mathrm{i}}$ responses involve different purinergic receptors, including $\mathrm{P}_{2} \mathrm{X}_{7}$ and $\mathrm{P}_{2} \mathrm{Y}_{1}$ receptors $(61,62)$, both being implicated in the hemichannel opening 


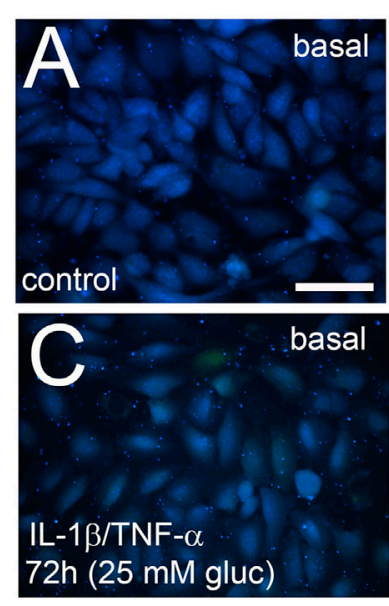

\section{E}
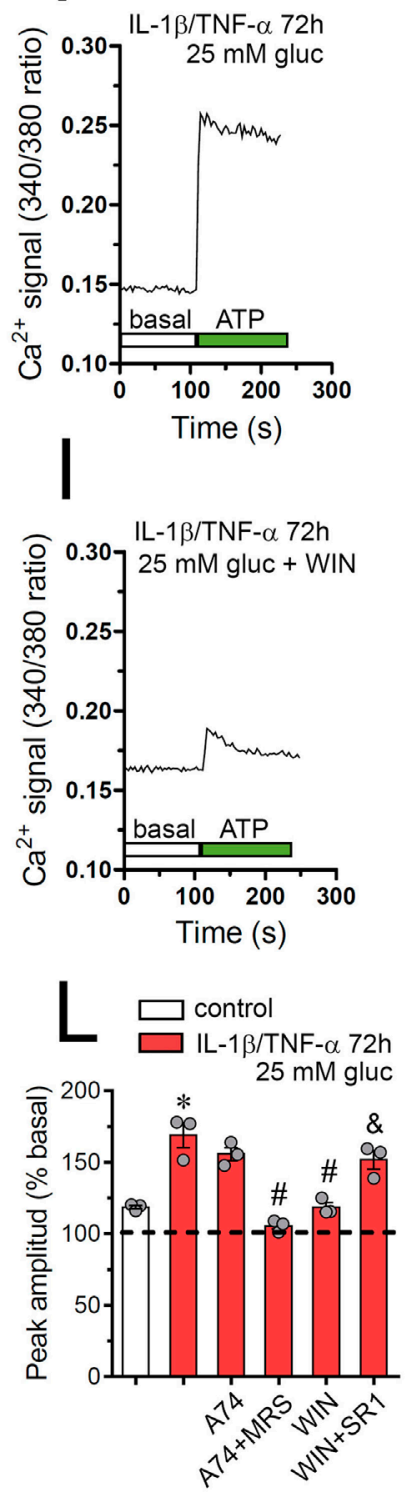
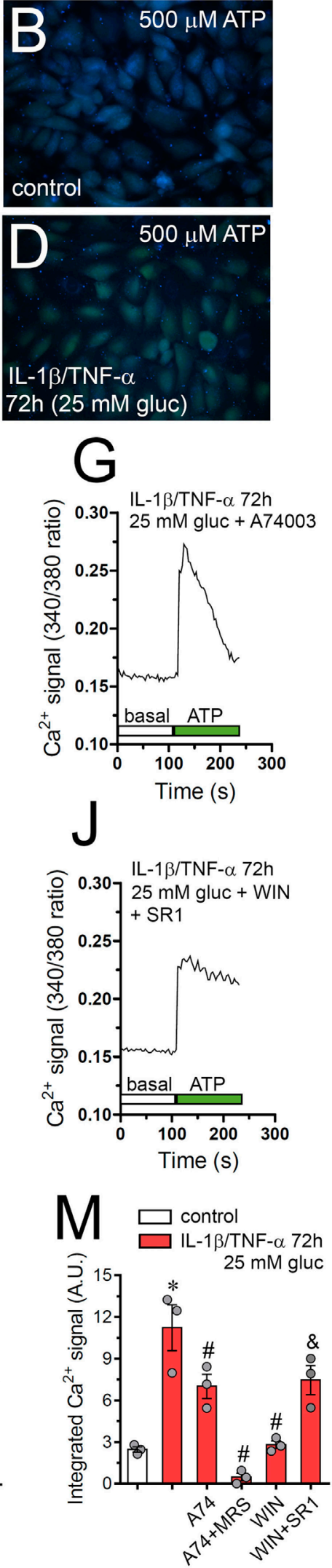
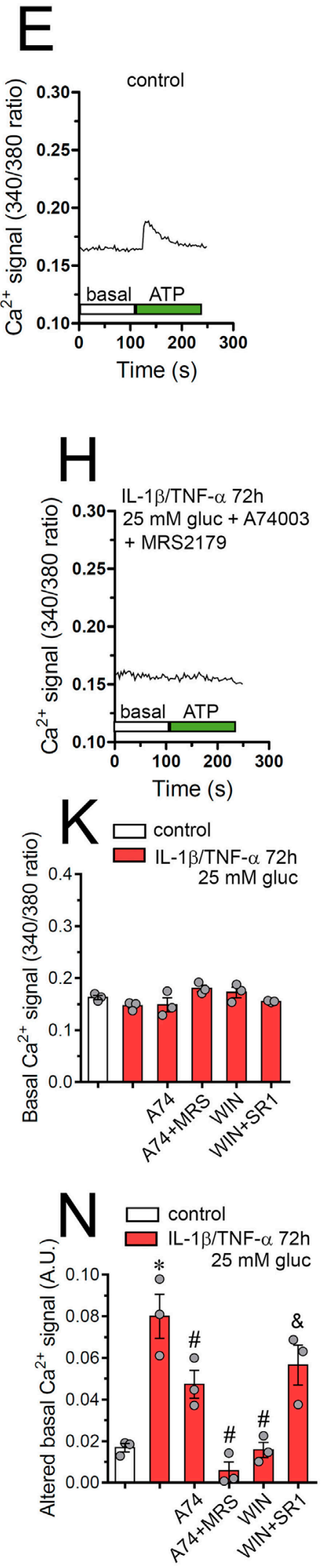
FIGURE 6 | High glucose and IL-1 $\beta / T N F-\alpha$ enhance ATP-dependent Ca ${ }^{2+}$ dynamics in endothelial cells: prevention by WIN. (A-D) Representative photomicrographs of basal (A,C) or $500 \mu \mathrm{M}$ ATP-induced (B,D) Ca ${ }^{2+}$ signal denoted as Fura-2 ratio (340/380 nm excitation) of EAhy cells treated for $72 \mathrm{~h}$ with $5 \mathrm{mM}$ glucose [control

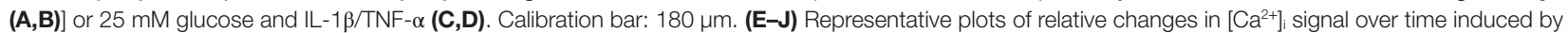
$500 \mu \mathrm{M}$ ATP (gray vertical line) in EAhy cells treated for $72 \mathrm{~h}$ with $5 \mathrm{mM}$ glucose [control (E)], $25 \mathrm{mM}$ glucose, and IL-1 $\beta / T N F-\alpha$ (F) alone or in combination with the following agents: $10 \mu \mathrm{M}$ A740003 (G), $10 \mu \mathrm{M}$ A740003 plus $10 \mu \mathrm{M}$ MRS2179 (H), $5 \mu \mathrm{M}$, WIN (I) and $5 \mu \mathrm{M}$, WIN plus $5 \mu \mathrm{M}$ SR-141716A [SR1 (J)]. (K) Averaged data of basal Fura-2 ratio by EAhy cells treated for $72 \mathrm{~h}$ with $5 \mathrm{mM}$ glucose (control, white bar), $25 \mathrm{mM}$ glucose, and IL-1 $\beta / T N F-\alpha$ (red bars) alone or in combination with the following agents: $10 \mu \mathrm{M}$ A740003 (A74), $10 \mu \mathrm{M}$ A740003 plus $10 \mu \mathrm{M}$ MRS2179 (A74 + MRS), $5 \mu \mathrm{M}$ WIN (WIN) and $5 \mu \mathrm{M}$, WIN plus $5 \mu \mathrm{M}$ SR-141716A (WIN + SR1). (L-N) Averaged data of ATP-induced peak amplitude normalized to basal Fura-2 ratio (L), integrated ATP-induced Fura-2 ratio response (M), and altered basal Fura-2 ratio (N) of EAhy cells treated for $72 \mathrm{~h}$ with $5 \mathrm{mM}$ glucose (control, white bar), $25 \mathrm{mM}$ glucose, and IL-1 $\beta / T N F-\alpha$ (red bars) alone or in combination with the following agents: $10 \mu \mathrm{M}$ A740003 (A74), $10 \mu \mathrm{M}$ A740003 plus $10 \mu \mathrm{M}$ MRS2179 (A74 + MRS), $5 \mu \mathrm{M}$ WIN (WIN) and $5 \mu \mathrm{M}$, WIN plus $5 \mu \mathrm{M}$ SR-141716A (WIN + SR1). ${ }^{*} p<0.05$, IL-1 $\beta / T N F-\alpha$ and high glucose compared to control; ${ }^{*} p<0.05$, effect of each pharmacological agent compared to the effect induced by IL-1 $\beta /$ TNF- $\alpha$ and high glucose; ${ }^{8} p<0.05$, effect of each cannabinoid receptor antagonist compared to the effect of the respective cannabinoid (one-way analysis of variance followed by Tukey's post hoc test). Data were obtained from at least three independent experiments (see scatter dot plot) with four repeats each one ( $\geq 35$ cells analyzed for each repeat).

triggered by IL-1 $\beta /$ TNF- $\alpha$ and high glucose (Figure $2 \mathrm{~A})$. Notably, blockade of $\mathrm{P}_{2} \mathrm{X}_{7}$ receptors with $10 \mu \mathrm{M}$ A740003 completely suppressed the sustained response pattern of ATP-mediated $\mathrm{Ca}^{2+}$ signal in IL-1 $\beta /$ TNF- $\alpha$ and high glucose-stimulated EAhy cells (Figure 6G). In addition, A740003 partially inhibited the integrated and remaining basal ATP-dependent $\mathrm{Ca}^{2+}$ signal responses (Figures $\mathbf{6 M}, \mathbf{N}$ ), but did not affect the peak amplitude induced by IL-1 $\beta /$ TNF- $\alpha$ and high glucose (Figure 6L). Notably, simultaneous inhibition of $\mathrm{P}_{2} \mathrm{X}_{7}$ and $\mathrm{P}_{2} \mathrm{Y}_{1}$ receptors with $10 \mu \mathrm{M}$ A740003 and $10 \mu \mathrm{M}$ MRS2179, respectively, completely blunted the ATP-dependent $\mathrm{Ca}^{2+}$ signal in IL- $1 \beta /$ TNF- $\alpha$ and high glucosestimulated EAhy cells (Figure 6H). The latter was paralleled with a total suppression of the IL- $1 \beta /$ TNF- $\alpha$ and high glucose-induced increase of the $\mathrm{Ca}^{2+}$ signal evoked by ATP (Figures $6 \mathrm{~L}-\mathrm{N}$ ). These findings indicate that upon ATP exposure, the transient peak in $\left[\mathrm{Ca}^{2+}\right]_{i}$ signal recorded in IL- $1 \beta /$ TNF- $\alpha$ and high glucosestimulated EAhy cells, likely came from $\mathrm{Ca}^{2+}$ released from intracellular stores due to stimulation of $\mathrm{P}_{2} \mathrm{Y}_{1}$ and $\mathrm{IP}_{3}$ receptors, whereas the following sustained $\mathrm{Ca}^{2+}$ signal could involve the participation of $\mathrm{P} 2 \mathrm{X}_{7}$ receptors. Interestingly, IL- $1 \beta / \mathrm{TNF}-\alpha$ and high glucose-stimulated EAhy cells showed ATP-mediated $\mathrm{Ca}^{2+}$ signals similar to those recorded in control conditions when they were pre-treated with $10 \mu \mathrm{M}$ WIN (Figures 6I,L-N). Moreover, WIN-induced prevention of ATP-induced $\mathrm{Ca}^{2+}$ signal did not occur in IL- $1 \beta /$ TNF- $\alpha$ and high glucose-stimulated EAhy cells co-incubated with the $\mathrm{CB}_{1}$ receptor antagonist SR1 (Figures 6J,L-N). The above data support that $\mathrm{CB}_{1}$ receptors are responsible of the WIN-mediated prevention in the disturbing actions of IL- $1 \beta /$ TNF- $\alpha$ and high glucose on the dynamics of ATP-mediated $\mathrm{Ca}^{2+}$ signals in endothelial cells.

\section{WIN and Blockers of Cx43 Hemichannels Prevent the NO Production of Endothelial Cells Treated With IL-1 $\beta /$ TNF- $\alpha$ and High Glucose}

Altered iNOS-derived NO production has been involved in the beginning of acute and chronic inflammatory conditions associated with diverse diseases, including arthritis, sepsis, ischemia/ reperfusion, diabetes, and atherosclerosis (63). Because LN-6, a specific iNOS blocker, strongly blunted the IL-1 $\beta /$ TNF- $\alpha$ and high glucose-mediated Etd uptake in EAhy cells (Figure 2A), we investigated whether $\mathrm{Cx} 43$ hemichannels also modulate NO production. DAF fluorescence experiments indicated that IL-1 $\beta /$ TNF- $\alpha$ and high glucose-treated EAhy cells exhibited a $\sim 2$-fold increase in basal NO amount compared with control values (Figures $\mathbf{7 A}, \mathbf{B}, \mathbf{G}$ ). Interestingly, treatment with $5 \mu \mathrm{M}$ WIN fully prevented the IL- $1 \beta /$ TNF- $\alpha$ and high glucose-induced increase in NO production, the latter response being dependent on $\mathrm{CB}_{1}$ receptors as SR1 abolished the counteracting action of WIN (Figures 7C,G). Insulin is a well-known inducer of NO production in normal endothelial cells, however, under inflammatory conditions, the insulin-mediated production of $\mathrm{NO}$ is impaired (64). In this context, we evaluated whether IL-1 $\beta$ / TNF- $\alpha$ and high glucose could disturb the insulin-mediated production of NO. As expected, 30 min treatment with $1 \mu \mathrm{M}$ insulin induced a $\sim 75 \%$ increase in NO levels in control EAhy cells (Figures 7D,G). Remarkably, IL-1 $\beta /$ TNF- $\alpha$ and high glucose increased in $\sim 1$-fold the insulin-mediated production of NO (Figures 7E,G), a response that was completely prevented by $5 \mu \mathrm{M}$ WIN (Figures 7F,G). Supporting the involvement of $\mathrm{CB}_{1}$ receptors in the latter phenomenon, the counteracting influence of WIN on the insulin-mediated NO production did not occur in EAhy cells stimulated with IL- $1 \beta / \mathrm{TNF}-\alpha$ and high glucose plus co-incubation with SR1 (Figure 7G). Finally, we found that $100 \mu \mathrm{M}$ gap19 or $100 \mu \mathrm{M}$ Tat-L2 co-applied along with IL-1 $\beta$ / TNF- $\alpha$ and high glucose, fully suppressed the IL- $1 \beta /$ TNF- $\alpha$ and high glucose-mediated potentiation in NO production induced by insulin, turning NO levels to control values (Figure 7G). Altogether, these results support that $\mathrm{Cx} 43$ hemichannels serve as a crucial step in the modulatory actions evoked by IL-1 $\beta$ / TNF- $\alpha$ and high glucose on insulin-mediated production of NO in endothelial cells.

\section{DISCUSSION}

Here, we demonstrated for the first time that high glucose concentrations elevate the $\mathrm{Cx} 43$ hemichannel activity in cultured endothelial cells. A mixture of IL- $1 \beta$ and TNF- $\alpha$, two pro-inflammatory cytokines that open hemichannels in different cell types $(19,20,22)$, enhanced this phenomenon. Furthermore, IL-1 $\beta /$ TNF- $\alpha$ and high glucose-induced $\mathrm{Cx} 43$ hemichannel activity was associated with ATP release and activation of p38 MAPK, iNOS, $\mathrm{COX}_{2}, \mathrm{PGE}_{2}$ receptor $\mathrm{EP}_{1}$, and $\mathrm{P} 2 \mathrm{X}_{7} / \mathrm{P}_{2} \mathrm{Y}_{1}$ receptors. In addition, 


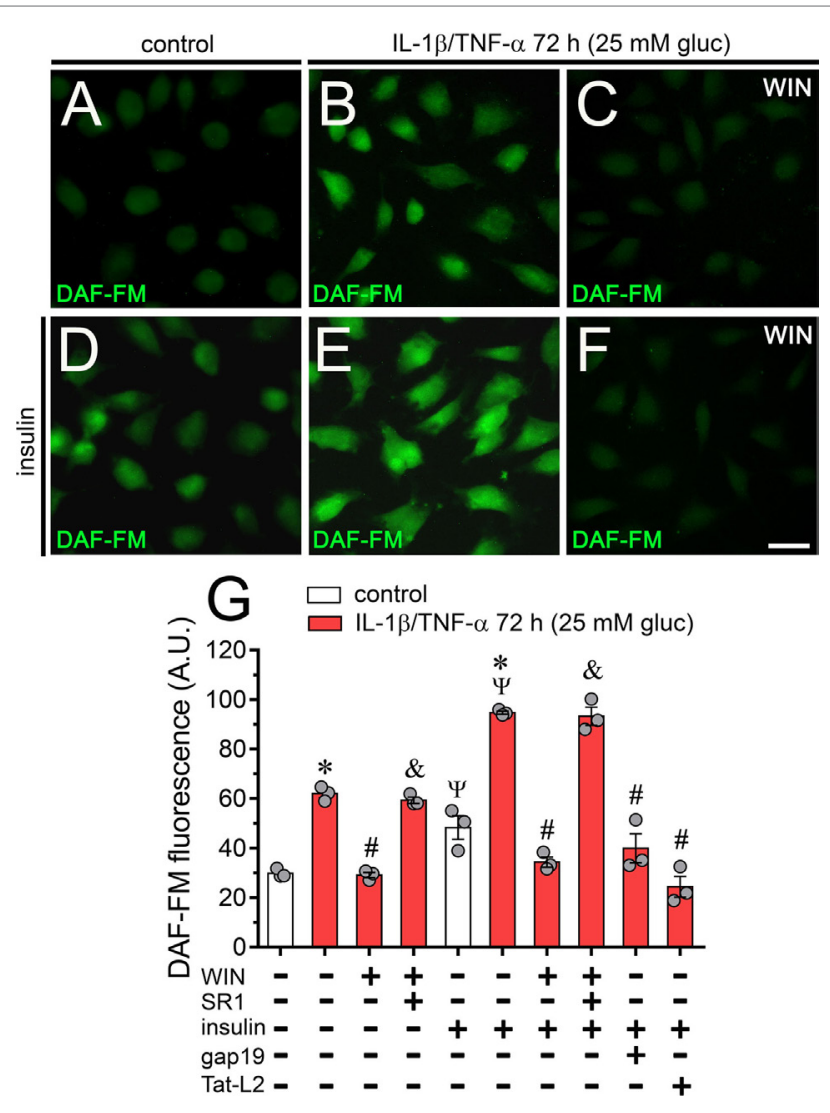

FIGURE 7 | High glucose and IL-1 $\beta / T N F-\alpha$ increase basal and insulininduced production of nitric oxide (NO) in endothelial cells: prevention by WIN and connexin 43 (Cx43) hemichannel blockers. (A-F) Representative fluorescence micrographs of basal (A-C) or $1 \mu \mathrm{M}$ insulin-induced (D-F) production of NO (DAF-FM, green and pseudo-colored scale) of EAhy cells treated for $72 \mathrm{~h}$ with $5 \mathrm{mM}$ glucose [control (A,D)], $25 \mathrm{mM}$ glucose, and $\mathrm{IL}-1 \beta / \mathrm{TNF}-\alpha \mathbf{( B , E )}$ alone or in combination with $5 \mu \mathrm{M}$ WIN (C,F). (G) Average of DAF fluorescence by EAhy cells treated for $72 \mathrm{~h}$ with $5 \mathrm{mM}$ glucose (control; white bars), $25 \mathrm{mM}$ glucose and IL-1 $\beta / \mathrm{TNF}-\alpha$ (red bars) alone or with different combinations of the following compounds: $5 \mu \mathrm{M}$ WIN $(\mathrm{WIN}), 5 \mu \mathrm{M}$ SR-141716A (SR1), $1 \mu \mathrm{M}$ insulin, $100 \mu \mathrm{M}$ gap19, and $100 \mu \mathrm{M}$ Tat-L2. ${ }^{*} p<0.05$, IL-1 $\beta / \mathrm{TNF}-\alpha$ and high glucose compared to control; ${ }^{*} p<0.05$, effect of each compound compared to the effect induced by IL-1 $1 \beta / \mathrm{TNF}-\alpha$ and high glucose; ${ }^{p} p<0.05$, effect of each cannabinoid receptor antagonist compared to the effect of the respective cannabinoid; ${ }^{\Psi} p<0.05$, effect of insulin compared to the respective control (one-way analysis of variance followed by Tukey's post hoc test). Data were obtained from at least three independent experiments (see scatter dot plot) with four repeats each one ( $\geq 35$ cells analyzed for each repeat). Calibration bar $=40 \mu \mathrm{m}$.

we describe that a synthetic CB: WIN, and two endogenous CBs; $2-A G$ and Meth; counteract the IL- $1 \beta /$ TNF- $\alpha$ and high glucose-mediated $\mathrm{Cx} 43$ hemichannel opening and subsequent ATP release. These CBs also counteract diverse cell endothelial alterations evoked by IL- $1 \beta /$ TNF- $\alpha$ plus high glucose, including the increase in ATP-mediated $\mathrm{Ca}^{2+}$ signals and $\mathrm{NO}$ production.

As assayed by Etd uptake, we demonstrated that $45 \mathrm{mM}$ glucose increments by itself the activity of Cx43 hemichannels in EAhy cells, whereas $25 \mathrm{mM}$ glucose did it only in combination with the mixture of IL- $1 \beta$ and TNF- $\alpha$. In fact, two specific mimetic peptides known to reduce $\mathrm{Cx} 43$ hemichannel opening (Tat-L2 and gap19), but not their inactive forms, significantly inhibited the IL- $1 \beta /$ TNF- $\alpha$ and high glucose-evoked Etd uptake. In addition, the latter effect did not occur in EAhy cells stimulated with siRNAs that downregulated $\mathrm{Cx} 43$. All these data indicate that IL-1 $\beta /$ TNF- $\alpha$ and high glucose specifically elevate the opening of Cx43 hemichannels in EAhy endothelial cells.

How do IL- $1 \beta /$ TNF- $\alpha$ and high glucose induce $\mathrm{Cx} 43$ hemichannel activity in EAhy endothelial cells? Prior research has determined that IL- $1 \beta$ and TNF- $\alpha$ or high glucose augment the functional state of $\mathrm{Cx} 43$ hemichannels via the p38 MAPK pathway and subsequent NO-mediated S-nitrosylation of $\mathrm{Cx} 43$ $(20,37,39)$. Moreover, $\mathrm{COX}$ and $\mathrm{PGE}_{2}$ receptor $\mathrm{EP}_{1}$ stimulation is necessary for the long-lasting $\mathrm{Cx} 43$ hemichannel activity elicited during inflammatory conditions (38). Here, by using a battery of selective inhibitors, we have shown that the IL- $1 \beta / \mathrm{TNF}-\alpha$ and high glucose-induced $\mathrm{Cx} 43$ hemichannel opening comprises the activation of both $\mathrm{p} 38 \mathrm{MAPK}$ and $\mathrm{NOS}$, as well as the stimulation of $\mathrm{PGE}_{2}$ receptor $\mathrm{EP}_{1}$. In addition, IL- $1 \beta / \mathrm{TNF}-\alpha$ and high glucose raised the production of $\mathrm{NO}$ in EAhy cells (see below). These findings are consistent with the fact that NO stimulates COXs and the subsequent production of $\mathrm{PGE}_{2}$ (42). The latter prostaglandin is essential for $\left[\mathrm{Ca}^{2+}\right]_{\mathrm{i}}$ elevations evoked by $\mathrm{EP}_{1}$ receptors (44), which are highly expressed in endothelial cells (65).

Multiple studies argue that pro-inflammatory cytokines or high glucose may contribute to a chronic activation of endothelial cells and thereby a long-term production of key "danger" signals, such as ATP (66-68), which is involved with vascular inflammation (62). In this context, two findings reveal that ATP signaling is fundamental in the opening of endothelial $\mathrm{Cx} 43$ hemichannels evoked by IL- $1 \beta /$ TNF- $\alpha$ and high glucose. First, we detected that blockade of both $\mathrm{P}_{2} \mathrm{X}_{7}$ and $\mathrm{P}_{2} \mathrm{Y}_{1}$ receptors partially abrogated the IL- $1 \beta /$ TNF- $\alpha$ and high glucose-induced Cx43 hemichannel activity. Second, the activity of $\mathrm{Cx} 43$ hemichannels was linked to the release of ATP in IL- $1 \beta /$ TNF- $\alpha$ and high glucose-stimulated EAhy cells. In conformity with this study, recent findings have elucidated that ATP elicits its own release via hemichannels and further stimulation of purinergic receptors $(8,38,39)$. Here, autocrine/paracrine release of ATP seems to govern $\mathrm{Cx} 43$ hemichannel activity as an alternative mechanism to that caused by p38 MAPK and NO production (Figure 8). The activity of $\mathrm{Cx} 43$ hemichannels could take place upon elevations in $\left[\mathrm{Ca}^{2+}\right]_{\mathrm{i}}$ caused by activation of $\mathrm{P}_{2} \mathrm{Y}_{1}$ or $\mathrm{P} 2 \mathrm{X}_{7}$ receptors $(8,38,39)$. Accordingly, prior evidence have described that a moderate rise in $\left[\mathrm{Ca}^{2+}\right]_{\mathrm{i}}(>500 \mathrm{nM})$ increase the open probability of $\mathrm{Cx} 43$ hemichannel opening $(6,34,45)$. In agreement with this evidence, we detected that chelation of $\left[\mathrm{Ca}^{2+}\right]_{i}$ with BAPTA totally blunted the IL- $1 \beta / \mathrm{TNF}-\alpha$ and high glucoseinduced Etd uptake in EAhy cells. In this scenario, endothelial $\mathrm{Cx} 43$ hemichannels could participate directly in the release of ATP, as they are permeable to this compound (69). Alternatively, because these channels are conduits for $\mathrm{Ca}^{2+}(70)$, they indirectly may contribute to perpetuate $\left[\mathrm{Ca}^{2+}\right]_{\mathrm{i}}$-dependent pathways associated with ATP release (e.g., exocytosis) (Figure 8). The intensity of this response might impact the outcome of the inflammation. In that regard, it has been demonstrated that opening of $\mathrm{Cx} 43$ hemichannels could lead to preconditioning (71) as well as to cell death (21). 


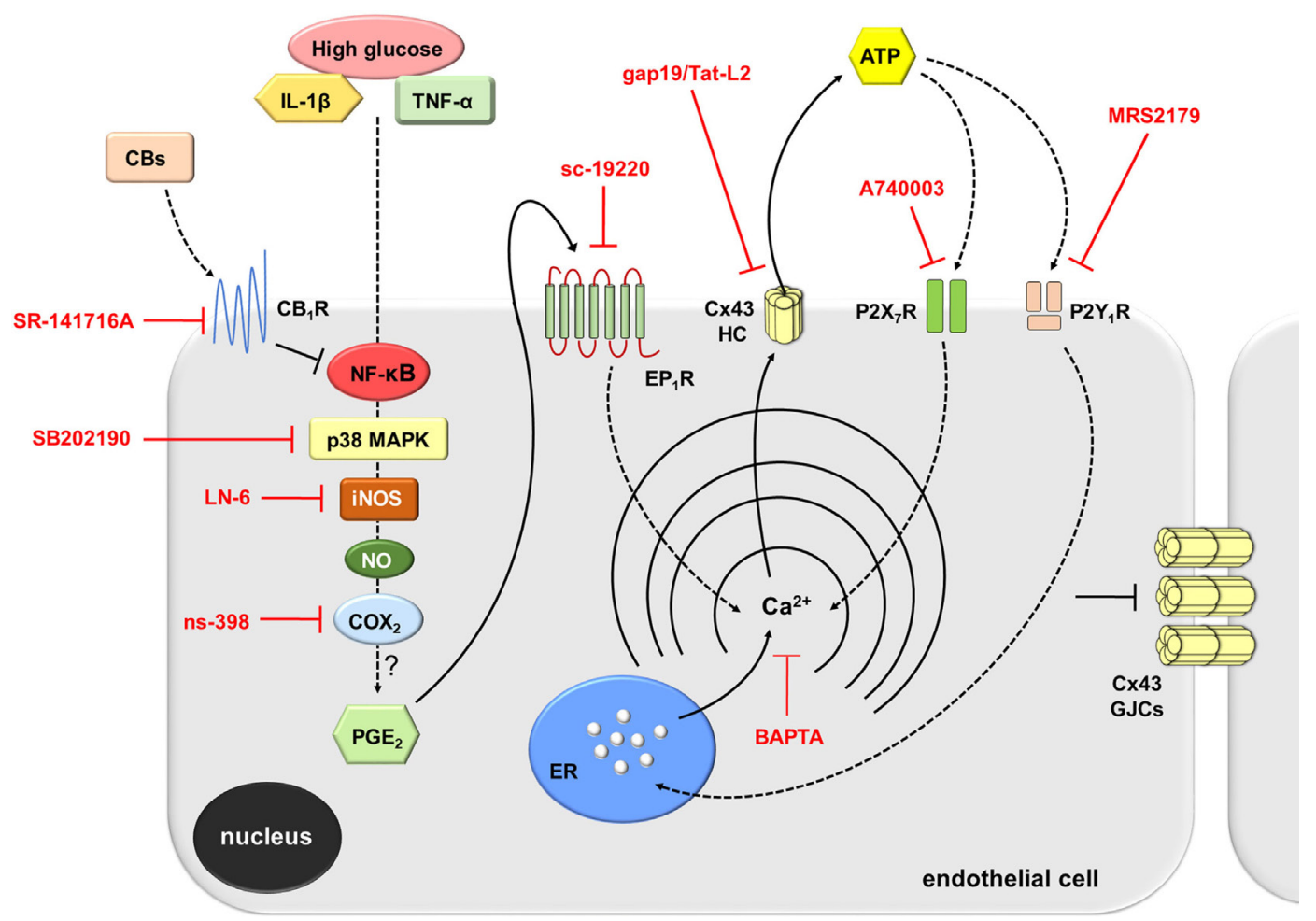

FIGURE 8 | Schematic diagram showing the possible pathways involved in the activation of connexin 43 (CX43) hemichannels evoked by high glucose and IL-1 $\beta /$ TNF- $\alpha$ in endothelial cells. Upon stimulation with high glucose and IL-1 $\beta / T N F-\alpha$, endothelial cells respond with intracellular signal transduction that possibly involve NF- $\kappa \beta$ signaling associated with $\mathrm{p38}$ MAPK and inducible NO synthase (iNOS) activation, nitric oxide (NO) production, and further stimulation of $\mathrm{COX}_{2}$. The latter likely induce the production of $\mathrm{PGE}_{2}$, which acting on $\mathrm{EP}_{1}$ metabotropic receptor promotes the release of $\mathrm{Ca}^{2+}$ from intracellular stores. Rise in [Ca $\left.{ }^{2+}\right]$, is a known condition that causes opening of $\mathrm{C} 43$ hemichannels enabling the release of ATP. ATP released via $\mathrm{C} \times 43$ hemichannels may activate $\mathrm{P} 2 \mathrm{X}_{7}$ receptors, and its degradation to ADP may stimulate P2Y, receptors. These events trigger the influx of extracellular $\mathrm{Ca}^{2+}$ and activation of $\mathrm{IP}_{3}$ receptors and further release of $\mathrm{Ca}^{2+}$ stored in the endoplasmic reticulum. The later induces an unknown self-perpetuating mechanism (see Discussion), in which high levels of [Ca $\left.{ }^{2+}\right]_{i}$ could reactivate iNOS, $\mathrm{COX}_{2}, \mathrm{EP}_{1}$ metabotropic receptors, and $\mathrm{Cx} 43$ hemichannels (not depicted). On the other hand, cannabinoids (CBs) acting on $\mathrm{CB}_{1}$ Rs possibly counteract the $\mathrm{NF}-\mathrm{\kappa} \beta$-dependent activation of the above-mentioned pathways. This response results in the inhibition of p38 MAPK and NO production, as well as the consequent reduction ATP release through $\mathrm{C} \times 43$ hemichannels. In parallel, activation of $\mathrm{CB}_{1} \mathrm{Rs}$ may neutralize the reduction in gap junction communication evoked by high glucose and IL-1 $\beta / T N F-\alpha$. Main inhibitors used throughout this study are shown in red.

Past research has established that plant-derived, synthetic, and endogenous CBs may provide protective actions against several cardiovascular pathologies, including ventricular arrhythmias (72) and cardiomyopathies (73). In fact, CBs diminish endothelial dysfunction by inhibiting the production of inflammatory mediators (e.g., free radical and cytokines) and their signaling pathways (e.g., NF- $\kappa \beta)(53,74)$. However, whether endothelial hemichannels are part of the targets involved in the anti-inflammatory actions of CBs remained unknown. Here, we observed that WIN, 2-AG, and Meth completely suppressed the Cx43 hemichannel-mediated Etd uptake induced by IL-1 $\beta$ / TNF- $\alpha$ and high glucose in EAhy cells. These preventive actions were completely neutralized by the $\mathrm{CB}_{1}$ receptor antagonist $\mathrm{SR} 1$, which is in according with the participation of $\mathrm{CB}_{1}$ receptors in Cx43 hemichannel opening $(48,50)$, as well as their demonstrated expression and function in endothelial cells (52, $75)$. Interestingly, WIN fully reduced not only the IL- $1 \beta /$ TNF- $\alpha$ and high glucose-induced Etd uptake but also significantly prevented the release of ATP triggered by these pro-inflammatory conditions. Similar inhibitory responses on $\mathrm{Cx} 43$ hemichanneldependent ATP release have been observed for CBs in activated astrocytes (50). Other mechanism of hemichannel modulation different of that resulting from covalent modifications (e.g., phosphorylation and/or S-nitrosylation) is the trafficking of hemichannels to non-junctional membranes. In this study, we demonstrated that WIN fully abrogated the IL- $1 \beta /$ TNF- $\alpha$ and high glucose-induced augment in plasma membrane levels of $\mathrm{Cx} 43$, revealing that alterations in surface protein expression are possibly sufficient to account for the regulation of hemichannel activity triggered by IL- $1 \beta /$ TNF- $\alpha$ and high glucose or CBs in EAhy cells. It is important to mention that pharmacotherapy involving CBs is still under intense debate. The latter is mainly due to the negative side effects that CBs may exert on the nervous system and peripheral glucose metabolism $(76,77)$ most likely due to their low affinity to the molecular targets. Future studies will elucidate whether or not targeting specifically endothelial cells with $\mathrm{CB}$ receptor agonists could counteract endothelial dysfunction in vivo. 
Multiple lines of work point out that hemichannels and gap junctions are contrarily modulated by inflammatory agents (78). In agreement with those observations, we noted that in addition to elevate endothelial $\mathrm{Cx} 43$ hemichannel activity, IL-1 $\beta / \mathrm{TNF}-\alpha$ and high glucose suppressed the cell-to-cell gap junctional communication in EAhy cells, as measured by intercellular LY diffusion. Relevantly, WIN fully prevented the IL- $1 \beta / \mathrm{TNF}-\alpha$ and high glucose-induced reduction in endothelial coupling via the activation of $\mathrm{CB} 1$ receptors. As deducted from western blot analysis, the modulation of dye coupling triggered by IL- $1 \beta$ / TNF- $\alpha$ and high glucose or WIN could be in part attributed to changes in Cx43 amount, namely, total reduction or increment, respectively. Moreover, immunofluorescence labeling showed no differences in the distribution of $\mathrm{Cx} 43$ in EAhy cells treated with IL- $1 \beta /$ TNF- $\alpha$ and high glucose alone or plus WIN, indicating that endocytosis or degradation of gap junctions do not account for the regulation of endothelial coupling.

Prior findings in diverse cell types, including endothelial cells, have revealed that ATP produces a biphasic $\left[\mathrm{Ca}^{2+}\right]_{i}$ response: the release of stored $\mathrm{Ca}^{2+}$ (first spike) and $\mathrm{Ca}^{2+}$ influx from the extracellular medium (sustained response) $(61,79)$. The first spike in ATP-elicited $\left[\mathrm{Ca}^{2+}\right]_{\mathrm{i}}$ response depends on $\mathrm{P} 2 \mathrm{Y}$ receptors, while the second sustained event take place due to P2X receptors. Here, we noticed that upon acute stimulation with ATP, control EAhy cells displayed a small $\mathrm{Ca}^{2+}$ signal peak that returned rapidly to control values. In contrast, IL- $1 \beta / \mathrm{TNF}-\alpha$ and high glucose-treated EAhy cells showed increased ATP-induced $\mathrm{Ca}^{2+}$ signals compared to control, particularly, in terms of peak amplitude, integrated area, and sustained signal. Notably, in these conditions the initial $\mathrm{Ca}^{2+}$ signal peak was inhibited by MRS2179, but not by $\mathrm{P}_{2} \mathrm{X}_{7}$ receptor blockers, suggesting the implication of metabotropic $\mathrm{P}_{2} \mathrm{Y}_{1}$ receptors. Given that $\mathrm{ADP}$ is the major ligand for $\mathrm{P}_{2} \mathrm{Y}_{1}$ receptors, and because they participate in endothelial $\mathrm{Ca}^{2+}$ dynamics (80), in our studies, ADP produced from ATP conversion possibly generated the $\mathrm{P} 2 \mathrm{Y}_{1}$-mediated changes in $\left[\mathrm{Ca}^{2+}\right]_{i}$ elicited by acute ATP application. On the other hand, the ATP-induced sustained $\mathrm{Ca}^{2+}$ signal detected in IL- $1 \beta /$ TNF- $\alpha$ and high glucose-stimulated EAhy cells was fully counteracted by blocking $\mathrm{P}_{2} \mathrm{X}_{7}$ receptors, indicating that influx of $\mathrm{Ca}^{2+}$ is also necessary for ATP-induced $\mathrm{Ca}^{2+}$ signal in EAhy cells. Interestingly, the above $\mathrm{Ca}^{2+}$ response associated with $\mathrm{P} 2 \mathrm{Y}_{1} / \mathrm{P} 2 \mathrm{X}_{7}$ receptors was completely inhibited by WIN-dependent activation of CB1 receptors in IL- $1 \beta /$ TNF- $\alpha$ and high glucose-stimulated EAhy cells. These data denote that ATPmediated $\mathrm{Ca}^{2+}$ dynamics depend on the inflammatory profile of endothelial cells and can be antagonized by the anti-inflammatory actions of CBs (Figure 8). ATP released from endothelial cells could activate distant cells in a paracrine form, resulting in $\mathrm{Ca}^{2+}$ responses that may rely on the endothelial inflammatory profile. In this scenario, stimulation of purinergic receptors may be shut down due to diffusion of ATP to far-off areas in conjunction with desensitization of $\mathrm{P} 2 \mathrm{Y}_{1}$ receptors and degradation of extracellular ATP via exonucleases.

In endothelial cells, NO can be produced from L-arginine in a reaction catalyzed by endothelial NO synthase (eNOS) and iNOS $(36,81)$. Yet despite both NOS isoforms catalyze the same biochemical reaction, eNOS and iNOS are very different enzymes, being the former involved in the constitutive NO production at nanomolar levels, whereas the latter generates micromolar amounts of NO only when stimulated (82). NO exerts important vasodilatory and protective effects on the vasculature (83). However, high NO production has been linked to the pathogenesis of chronic inflammatory diseases, including atherosclerosis (63). Relevant to this point, previous studies have revealed that pro-inflammatory conditions (e.g., high glucose) elicit the formation of endothelial $\mathrm{NO}(36,84)$. In agreement with this information, we identify that IL- $1 \beta / \mathrm{TNF}-\alpha$ and high glucose clearly increase NO production in EAhy cells, which could be an alternative mechanism of hemichannel regulation through the S-nitrosylation of Cx43 (37).

Insulin is a direct-acting vasodilator in intact vessels (85) and has been described to induce the production of NO in normal endothelial cells (86). Nevertheless, endothelial cells subjected to pro-inflammatory conditions, such as high glucose and cytokine treatment, loss the ability to form $\mathrm{NO}(87,88)$. As expected, in control EAhy cells, insulin promoted an evident augment in NO production. Surprisingly, in EAhy cells stimulated with IL-1 $\beta$ / TNF- $\alpha$ and high glucose, the insulin-mediated NO production was higher than that of control conditions, revealing that insulin sensitivity is not inhibited. This unexpected finding might occur by the degree of inflammation developed by EAhy cells under the pro-inflammatory treatment used. Perhaps the NO response to insulin treatment become reduced at later time points not analyzed in the present work or the application of more intense proinflammatory conditions is required to develop that outcome. As occurred with IL- $1 \beta / \mathrm{TNF}-\alpha$ and high glucose-induced changes in hemichannel opening, ATP release and $\left[\mathrm{Ca}^{2+}\right]_{\mathrm{i}}$ dynamics, the enhanced production of NO was greatly prevented by the activation of $\mathrm{CB}_{1}$ receptors with WIN.

High glucose and IL- $1 \beta / \mathrm{TNF}-\alpha$ are well established conditions that disturb vascular homeostasis through different cellular and molecular mechanisms (5). Here, we identify the function of endothelial Cx43 hemichannels as a new pathway affected by inflammatory mediators, revealing their possible implication in the pathogenesis of multiple vascular diseases. Supporting this idea, the increased production of NO caused by IL- $1 \beta /$ TNF- $\alpha$ and high glucose was completely impeded by blockade of endothelial $\mathrm{Cx} 43$ hemichannels. Furthermore, this study demonstrated that intracellular $\mathrm{Ca}^{2+}$ associated with $\mathrm{COX}_{2} / \mathrm{EP}_{1}$ receptor signaling and purinergic receptor activation-likely via ATP release-are crucial to maintain persistent opening of $\mathrm{Cx} 43$ hemichannels and possibly for preserving the p38 MAPK-dependent NO production observed in IL-1 $\beta$ / TNF- $\alpha$ and high glucose-stimulated endothelial cells. The above may reproduce a self-perpetuating mechanism, in which both NO or high $\left[\mathrm{Ca}^{2+}\right]_{i}$ levels could reactivate $\mathrm{Cx} 43$ hemichannels (Figure 8). This phenomenon likely may lead to cell death, either by $\mathrm{Ca}^{2+}$ overload or through the reaction of $\mathrm{NO}$ with the superoxide anion, which yield peroxynitrite, a potent oxidant that alters DNA, lipids and proteins. We propose that reduction of hemichannel activity by $\mathrm{CB}$ agonists or selective hemichannel blockers might represent a strategy against the activation of deleterious pathways that trigger endothelial dysfunction and possibly cell damage evoked by high glucose and pro-inflammatory cytokines. The latter should favor the generation and design of 
novel CB agonists that could preserve their positive role without having side effects in general physiology.

\section{ETHICS STATEMENT}

This study was carried out in accordance with the recommendations of the Animal Care Guidelines of the Research Ethic Committee from the Pontificia Universidad Católica de Chile. The protocol was approved by Research Ethic Committee from the Pontificia Universidad Católica de Chile.

\section{AUTHOR CONTRIBUTIONS}

Conceived, performed, and analyzed the experiments: JAO, JCS, VV, SC-D, GG, VL, CS, RG-G, BA, ED, and TM. Wrote and edited the manuscript: JAO, JCS, and VV. All authors read and approved the final manuscript.

\section{ACKNOWLEDGMENTS}

CONICYT, PIA, FONDECYT, ICM, and Pontificia Universidad Católica de Chile.

\section{FUNDING}

This work was supported by the Fondo Nacional de Desarrollo Científico y Tecnológico (FONDECYT) Grant 1160710 (to JAO), 1150291 (to JCS), the Comisión Nacional de Investigación Científica y Tecnológica (CONICYT) and Programa de Investigación Asociativa (PIA) Grant Anillo de Ciencia y Tecnología ACT1411 (to JAO), P09-022-F from ICM-ECONOMIA, Chile (to JCS).

\section{REFERENCES}

1. McCarron JG, Lee MD, Wilson C. The endothelium solves problems that endothelial cells do not know exist. Trends Pharmacol Sci (2017) 38:322-38. doi:10.1016/j.tips.2017.01.008

2. Pober JS, Sessa WC. Inflammation and the blood microvascular system. Cold Spring Harb Perspect Biol (2014) 7:a016345. doi:10.1101/cshperspect. a016345

3. Vestweber D. How leukocytes cross the vascular endothelium. Nat Rev Immunol (2015) 15:692-704. doi:10.1038/nri3908

4. Cahill PA, Redmond EM. Vascular endothelium - gatekeeper of vessel health. Atherosclerosis (2016) 248:97-109. doi:10.1016/j.atherosclerosis.2016.03.007

5. Hansen NW, Hansen AJ, Sams A. The endothelial border to health: mechanistic evidence of the hyperglycemic culprit of inflammatory disease acceleration. IUBMB Life (2017) 69:148-61. doi:10.1002/iub.1610

6. Meunier C, Wang N, Yi C, Dallerac G, Ezan P, Koulakoff A, et al. Contribution of astroglial $\mathrm{Cx} 43$ hemichannels to the modulation of glutamatergic currents by D-serine in the mouse prefrontal cortex. J Neurosci (2017) 37:9064-75. doi:10.1523/JNEUROSCI.2204-16.2017

7. Bol M, Wang N, De Bock M, Wacquier B, Decrock E, Gadicherla A, et al. At the cross-point of connexins, calcium, and ATP: blocking hemichannels inhibits vasoconstriction of rat small mesenteric arteries. Cardiovasc Res (2017) 113:195-206. doi:10.1093/cvr/cvw215

8. Orellana JA, Sáez PJ, Cortes-Campos C, Elizondo RJ, Shoji KF, ContrerasDuarte $\mathrm{S}$, et al. Glucose increases intracellular free $\mathrm{Ca}(2+)$ in tanycytes via ATP released through connexin 43 hemichannels. Glia (2012) 60:53-68. doi:10.1002/glia.21246

9. Sáez JC, Leybaert L. Hunting for connexin hemichannels. FEBS Lett (2014) 588:1205-11. doi:10.1016/j.febslet.2014.03.004

\section{SUPPLEMENTARY MATERIAL}

The Supplementary Material for this article can be found online at https://www.frontiersin.org/articles/10.3389/fimmu.2018.01899/ full\#supplementary-material.

FIGURE S1 | Etd uptake induced by high glucose and IL-1 $\beta / \mathrm{TNF}-\alpha$ is not related to osmolarity changes, whereas high glucose/IL-1 $\beta / \mathrm{TNF}-\alpha$ plus WIN do not affect connexin 43 (Cx43) distribution in endothelial cells. (A) Averaged Etd uptake rate normalized with respect to control condition (dashed line) of EAhy cells treated for $72 \mathrm{~h}$ with $5 \mathrm{mM}$ glucose and IL-1 $/ \mathrm{TNF}-\alpha$ alone or in combination with 20 or $40 \mathrm{mM}$ sucrose or 20 or $40 \mathrm{mM}$ mannitol. Data were obtained from three independent experiments (see scatter dot plot) with two repeats each one $(\geq 35$ cells analyzed for each repeat). (B,C) Representative fluorescence images depicting Cx43 (green), tubulin (red), and DAPI (blue) immunolabeling of EAhy cells treated for $72 \mathrm{~h}$ with $25 \mathrm{mM}$ glucose plus IL-1 $\beta / \mathrm{TNF}-\alpha$ and $5 \mu \mathrm{M}$ WIN. Insets: $1.7 \times$ magnification of the indicated area of panels $\mathbf{( C )}$. Calibration bars: white $=35 \mu \mathrm{m}$, yellow $=60 \mu \mathrm{m}$, and green $=25 \mu \mathrm{m}$.

FIGURE S2 | High glucose and IL-1 $\beta /$ TNF- $\alpha$ increase the activity of connexin 43 hemichannels and nitric oxide production in HUVEC endothelial cells. (A) Averaged Etd uptake rate normalized with control condition (dashed line) by HUVEC cells treated for $72 \mathrm{~h}$ with $25 \mathrm{mM}$ glucose and IL-1 $\beta / T N F-\alpha$ alone or in combination with the following blockers: $100 \mu \mathrm{M}$ gap26, $100 \mu \mathrm{M}{ }^{10}$ panx1, $10 \mu \mathrm{M}$ WIN or $5 \mu \mathrm{M}$ WIN plus $5 \mu \mathrm{M}$ SR-141716A (SR1). ${ }^{*} p<0.05$, IL-1 $\beta / T N F-\alpha$ and high glucose compared to control; ${ }^{*} p<0.05$, effect of blockers compared IL-1 $\beta / \mathrm{TNF}-\alpha$ and high glucose. (B) Average of DAF fluorescence by HUVEC cells treated for $72 \mathrm{~h}$ with $5 \mathrm{mM}$ glucose (control; white bars), $25 \mathrm{mM}$ glucose and IL-1 $\beta / \mathrm{TNF}-\alpha$ (red bars) alone or with different combinations of the following compounds: $5 \mu \mathrm{M}$ WIN (WIN), $5 \mu \mathrm{M}$ SR-141716A (SR1), $1 \mu \mathrm{M}$ insulin or $100 \mu \mathrm{M}$ gap26. ${ }^{*} p<0.05$, IL-1 $\beta / \mathrm{TNF}-\alpha$ and high glucose compared to control; $* p<0.05$, effect of each compound compared to the effect induced by $\mathrm{L}-1 \beta / \mathrm{TNF}-\alpha$ and high glucose; $\& p<0.05$, effect of each cannabinoid receptor antagonist compared to the effect of the respective cannabinoid; ${ }^{\Psi} p<0.05$, effect of insulin compared to the respective control (one-way analysis of variance followed by Tukey's post hoc test). Data were obtained from three independent experiments (see scatter dot plot) with three repeats each one ( $\geq 35$ cells analyzed for each repeat).

10. Sáez JC, Berthoud VM, Branes MC, Martinez AD, Beyer EC. Plasma membrane channels formed by connexins: their regulation and functions. Physiol Rev (2003) 83:1359-400. doi:10.1152/physrev.00007.2003

11. Leybaert L, Lampe PD, Dhein S, Kwak BR, Ferdinandy P, Beyer EC, et al. Connexins in cardiovascular and neurovascular health and disease: pharmacological implications. Pharmacol Rev (2017) 69:396-478. doi:10.1124/ pr.115.012062

12. Kim Y, Davidson JO, Gunn KC, Phillips AR, Green CR, Gunn AJ. Role of hemichannels in CNS inflammation and the inflammasome pathway. Adv Protein Chem Struct Biol (2016) 104:1-37. doi:10.1016/bs.apcsb. 2015.12.001

13. Esposito K, Nappo F, Marfella R, Giugliano G, Giugliano F, Ciotola M, et al. Inflammatory cytokine concentrations are acutely increased by hyperglycemia in humans: role of oxidative stress. Circulation (2002) 106:2067-72. doi:10.1161/01.CIR.0000034509.14906.AE

14. Stentz FB, Umpierrez GE, Cuervo R, Kitabchi AE. Proinflammatory cytokines, markers of cardiovascular risks, oxidative stress, and lipid peroxidation in patients with hyperglycemic crises. Diabetes (2004) 53:2079-86. doi:10.2337/ diabetes.53.8.2079

15. Ling PR, Mueller C, Smith RJ, Bistrian BR. Hyperglycemia induced by glucose infusion causes hepatic oxidative stress and systemic inflammation, but not STAT3 or MAP kinase activation in liver in rats. Metabolism (2003) 52:868-74. doi:10.1016/S0026-0495(03)00057-X

16. Li J, Huang $M$, Shen $X$. The association of oxidative stress and pro-inflammatory cytokines in diabetic patients with hyperglycemic crisis. J Diabetes Complications (2014) 28:662-6. doi:10.1016/j.jdiacomp.2014.06.008

17. Urata Y, Yamamoto H, Goto S, Tsushima H, Akazawa S, Yamashita S, et al. Long exposure to high glucose concentration impairs the responsive expression of gamma-glutamylcysteine synthetase by interleukin-1beta and tumor necrosis 
factor-alpha in mouse endothelial cells. J Biol Chem (1996) 271:15146-52. doi:10.1074/jbc.271.25.15146

18. Nahomi RB, Palmer A, Green KM, Fort PE, Nagaraj RH. Pro-inflammatory cytokines downregulate Hsp27 and cause apoptosis of human retinal capillary endothelial cells. Biochim Biophys Acta (2014) 1842:164-74. doi:10.1016/j. bbadis.2013.11.011

19. Takeuchi H, Jin S, Wang J, Zhang G, Kawanokuchi J, Kuno R, et al. Tumor necrosis factor-alpha induces neurotoxicity via glutamate release from hemichannels of activated microglia in an autocrine manner. J Biol Chem (2006) 281(30):21362-8. doi:10.1074/jbc.M600504200

20. Retamal MA, Froger N, Palacios-Prado N, Ezan P, Sáez PJ, Sáez JC, et al. Cx43 hemichannels and gap junction channels in astrocytes are regulated oppositely by proinflammatory cytokines released from activated microglia. J Neurosci (2007) 27:13781-92. doi:10.1523/JNEUROSCI.2042-07.2007

21. Orellana JA, Hernandez DE, Ezan P, Velarde V, Bennett MV, Giaume C, et al. Hypoxia in high glucose followed by reoxygenation in normal glucose reduces the viability of cortical astrocytes through increased permeability of connexin 43 hemichannels. Glia (2010) 58:329-43. doi:10.1002/glia.20926

22. Abudara V, Roux L, Dallerac G, Matias I, Dulong J, Mothet JP, et al. Activated microglia impairs neuroglial interaction by opening Cx43 hemichannels in hippocampal astrocytes. Glia (2015) 63:795-811. doi:10.1002/glia.22785

23. Mugisho OO, Green CR, Kho DT, Zhang J, Graham ES, Acosta ML, et al. The inflammasome pathway is amplified and perpetuated in an autocrine manner through connexin 43 hemichannel mediated ATP release. Biochim Biophys Acta (2018) 1862:385-93. doi:10.1016/j.bbagen.2017.11.015

24. Cea LA, Riquelme MA, Cisterna BA, Puebla C, Vega JL, Rovegno M, et al. Connexin- and pannexin-based channels in normal skeletal muscles and their possible role in muscle atrophy. J Membr Biol (2012) 245:423-36. doi:10.1007/ s00232-012-9485-8

25. Hernandez-Salinas R, Vielma AZ, Arismendi MN, Boric MP, Sáez JC, Velarde V. Boldine prevents renal alterations in diabetic rats. J Diabetes Res (2013) 2013:593672. doi:10.1155/2013/593672

26. Johnson RG, Le HC, Evenson K, Loberg SW, Myslajek TM, Prabhu A, et al. Connexin hemichannels: methods for dye uptake and leakage. J Membr Biol (2016) 249:713-41. doi:10.1007/s00232-016-9925-y

27. Robertson J, Lang S, Lambert PA, Martin PE. Peptidoglycan derived from Staphylococcus epidermidis induces Connexin 43 hemichannel activity with consequences on the innate immune response in endothelial cells. Biochem $J$ (2010) 432:133-43. doi:10.1042/BJ20091753

28. Danesh-Meyer HV, Kerr NM, Zhang J, Eady EK, O'carroll SJ, Nicholson LF, et al. Connexin 43 mimetic peptide reduces vascular leak and retinal ganglion cell death following retinal ischaemia. Brain (2012) 135:506-20. doi:10.1093/ brain/awr338

29. D’Hondt C, Himpens B, Bultynck G. Mechanical stimulation-induced calcium wave propagation in cell monolayers: the example of bovine corneal endothelial cells. J Vis $\operatorname{Exp}$ (2013) 77:e50443. doi:10.3791/50443

30. Godecke S, Roderigo C, Rose CR, Rauch BH, Godecke A, Schrader J. Thrombin-induced ATP release from human umbilical vein endothelial cells. Am J Physiol Cell Physiol (2012) 302:C915-23. doi:10.1152/ajpcell.00283.2010

31. Kaneko Y, Tachikawa M, Akaogi R, Fujimoto K, Ishibashi M, Uchida Y, et al. Contribution of pannexin 1 and connexin 43 hemichannels to extracellular calcium-dependent transport dynamics in human blood-brain barrier endothelial cells. J Pharmacol Exp Ther (2015) 353:192-200. doi:10.1124/ jpet.114.220210

32. Bond SR, Naus CC. The pannexins: past and present. Front Physiol (2014) 5:58. doi:10.3389/fphys.2014.00058

33. Ponsaerts R, De Vuyst E, Retamal M, D’hondt C, Vermeire D, Wang N, et al. Intramolecular loop/tail interactions are essential for connexin 43-hemichannel activity. FASEB J (2010) 24:4378-95. doi:10.1096/f.09-153007

34. Wang N, De Bock M, Decrock E, Bola M, Gadicherla A, Bultynck G, et al. Connexin targeting peptides as inhibitors of voltage- and intracellular Ca2+triggered Cx43 hemichannel opening. Neuropharmacology (2013) 75:506-16. doi:10.1016/j.neuropharm.2013.08.021

35. Kuwano T, Nakao S, Yamamoto H, Tsuneyoshi M, Yamamoto T, Kuwano M, et al. Cyclooxygenase 2 is a key enzyme for inflammatory cytokine-induced angiogenesis. FASEB J (2004) 18:300-10. doi:10.1096/f.03-0473com

36. Cortese-Krott MM, Kulakov L, Oplander C, Kolb-Bachofen V, Kroncke KD, Suschek CV. Zinc regulates iNOS-derived nitric oxide formation in endothelial cells. Redox Biol (2014) 2:945-54. doi:10.1016/j.redox.2014.06.011
37. Retamal MA, Cortes CJ, Reuss L, Bennett MV, Sáez JC. S-nitrosylation and permeation through connexin 43 hemichannels in astrocytes: induction by oxidant stress and reversal by reducing agents. Proc Natl Acad Sci U S A (2006) 103:4475-80. doi:10.1073/pnas.0511118103

38. Orellana JA, Busso D, Ramirez G, Campos M, Rigotti A, Eugenin J, et al. Prenatal nicotine exposure enhances $\mathrm{Cx} 43$ and Panx1 unopposed channel activity in brain cells of adult offspring mice fed a high-fat/cholesterol diet. Front Cell Neurosci (2014) 8:403. doi:10.3389/fncel.2014.00403

39. Avendano BC, Montero TD, Chavez CE, Von Bernhardi R, Orellana JA. Prenatal exposure to inflammatory conditions increases Cx43 and Panx1 unopposed channel opening and activation of astrocytes in the offspring effect on neuronal survival. Glia (2015) 63(11):2058-72. doi:10.1002/glia.22877

40. Liu ZF, Zheng D, Fan GC, Peng T, Su L. Heat stress prevents lipopolysaccharide-induced apoptosis in pulmonary microvascular endothelial cells by blocking calpain/p38 MAPK signalling. Apoptosis (2016) 21:896-904. doi:10.1007/s10495-016-1263-0

41. Pan W, Yu H, Huang S, Zhu P. Resveratrol protects against TNF-alpha-induced injury in human umbilical endothelial cells through promoting sirtuin-1-induced repression of NF-KB and p38 MAPK. PLoS One (2016) 11:e147034. doi:10.1371/journal.pone.0147034

42. Swierkosz TA, Mitchell JA, Warner TD, Botting RM, Vane JR. Co-induction of nitric oxide synthase and cyclo-oxygenase: interactions between nitric oxide and prostanoids. Br J Pharmacol (1995) 114:1335-42. doi:10.1111/j.1476-5381. 1995.tb13353.x

43. Park S, Sung B, Jang EJ, Kim DH, Park CH, Choi YJ, et al. Inhibitory action of salicylideneamino-2-thiophenol on NF-kappaB signaling cascade and cyclooxygenase-2 in HNE-treated endothelial cells. Arch Pharm Res (2013) 36:880-9. doi:10.1007/s12272-013-0116-4

44. Woodward DF, Jones RL, Narumiya S. International Union of basic and clinical pharmacology. LXXXIII: classification of prostanoid receptors, updating 15 years of progress. Pharmacol Rev (2011) 63:471-538. doi:10.1124/pr.110.003517

45. De Bock M, Wang N, Bol M, Decrock E, Ponsaerts R, Bultynck G, et al. Connexin 43 hemichannels contribute to cytoplasmic $\mathrm{Ca} 2+$ oscillations by providing a bimodal Ca2+-dependent Ca2+ entry pathway. J Biol Chem (2012) 287:12250-66. doi:10.1074/jbc.M111.299610

46. Baroja-Mazo A, Barbera-Cremades M, Pelegrin P. The participation of plasma membrane hemichannels to purinergic signaling. Biochim Biophys Acta (2013) 1828:79-93. doi:10.1016/j.bbamem.2012.01.002

47. Chi Y, Gao K, Li K, Nakajima S, Kira S, Takeda M, et al. Purinergic control of AMPK activation by ATP released through connexin 43 hemichannels - pivotal roles in hemichannel-mediated cell injury. J Cell Sci (2014) 127:1487-99. doi:10.1242/jcs.139089

48. Froger N, Orellana JA, Cohen-Salmon M, Ezan P, Amigou E, Sáez JC, et al. Cannabinoids prevent the opposite regulation of astroglial connexin 43 hemichannels and gap junction channels induced by pro-inflammatory treatments. J Neurochem (2009) 111:1383-97. doi:10.1111/j.1471-4159.2009.06407.x

49. Froger N, Orellana JA, Calvo CF, Amigou E, Kozoriz MG, Naus CC, et al. Inhibition of cytokine-induced connexin 43 hemichannel activity in astrocytes is neuroprotective. Mol Cell Neurosci (2010) 45:37-46. doi:10.1016/j. mcn.2010.05.007

50. Gajardo-Gomez R, Labra VC, Maturana CJ, Shoji KF, Santibanez CA, Sáez JC, et al. Cannabinoids prevent the amyloid beta-induced activation of astroglial hemichannels: a neuroprotective mechanism. Glia (2017) 65:122-37. doi:10.1002/glia.23080

51. Piomelli D. The molecular logic of endocannabinoid signalling. Nat Rev Neurosci (2003) 4:873-84. doi:10.1038/nrn1247

52. Gasperi V, Evangelista D, Chiurchiu V, Florenzano F, Savini I, Oddi S, et al. 2-Arachidonoylglycerol modulates human endothelial cell/leukocyte interactions by controlling selectin expression through $\mathrm{CB} 1$ and $\mathrm{CB} 2$ receptors. Int J Biochem Cell Biol (2014) 51:79-88. doi:10.1016/j.biocel.2014.03.028

53. Wilhelmsen K, Khakpour S, Tran A, Sheehan K, Schumacher M, Xu F, et al. The endocannabinoid/endovanilloid $\mathrm{N}$-arachidonoyl dopamine (NADA) and synthetic cannabinoid WIN55,212-2 abate the inflammatory activation of human endothelial cells. J Biol Chem (2014) 289:13079-100. doi:10.1074/ jbc.M113.536953

54. Schalper KA, Palacios-Prado N, Retamal MA, Shoji KF, Martinez AD, Sáez JC. Connexin hemichannel composition determines the FGF-1-induced membrane permeability and free [Ca2+]i responses. Mol Biol Cell (2008) 19:3501-13. doi:10.1091/mbc.e07-12-1240 
55. Figueroa XF, Duling BR. Gap junctions in the control of vascular function. Antioxid Redox Signal (2009) 11:251-66. doi:10.1089/ars.2008.2117

56. Kim Y, Griffin JM, Harris PWR, Chan SHC, Nicholson LFB, Brimble MA, et al. Characterizing the mode of action of extracellular connexin 43 channel blocking mimetic peptides in an in vitro ischemia injury model. Biochim Biophys Acta (2017) 1861:68-78. doi:10.1016/j.bbagen.2016.11.001

57. McDonald B, Pittman K, Menezes GB, Hirota SA, Slaba I, Waterhouse CCM, et al. Intravascular danger signals guide neutrophils to sites of sterile inflammation. Science (2010) 330:362-6. doi:10.1126/science.1195491

58. Moccia F, Tanzi F, Munaron L. Endothelial remodelling and intracellular calcium machinery. Curr Mol Med (2014) 14:457-80. doi:10.2174/15665240 13666131118113410

59. Di A, Mehta D, Malik AB. ROS-activated calcium signaling mechanisms regulating endothelial barrier function. Cell Calcium (2016) 60:163-71. doi:10.1016/j.ceca.2016.02.002

60. De Bock M, Wang N, Decrock E, Bol M, Gadicherla AK, Culot M, et al. Endothelial calcium dynamics, connexin channels and blood-brain barrier function.ProgNeurobiol(2013) 108:1-20.doi:10.1016/j.pneurobio.2013.06.001

61. Lyubchenko T, Woodward H, Veo KD, Burns N, Nijmeh H, Liubchenko GA, et al. P2Y1 and P2Y13 purinergic receptors mediate Ca2+ signaling and proliferative responses in pulmonary artery vasa vasorum endothelial cells. Am J Physiol Cell Physiol (2011) 300:C266-75. doi:10.1152/ajpcell.00237.2010

62. Green JP, Souilhol C, Xanthis I, Martinez-Campesino L, Bowden NP, Evans PC, et al. Atheroprone flow activates inflammation via endothelial ATP-dependent P2X7-p38 signalling. Cardiovasc Res (2018) 114:324-35. doi:10.1093/cvr/cvx213

63. Lind M, Hayes A, Caprnda M, Petrovic D, Rodrigo L, Kruzliak P, et al. Inducible nitric oxide synthase: good or bad? Biomed Pharmacother (2017) 93:370-5. doi:10.1016/j.biopha.2017.06.036

64. Muniyappa R, Sowers JR. Role of insulin resistance in endothelial dysfunction. Rev Endocr Metab Disord (2013) 14:5-12. doi:10.1007/s11154-012-9229-1

65. Bundey RA, Insel PA. Adenylyl cyclase 6 overexpression decreases the permeability of endothelial monolayers via preferential enhancement of prostacyclin receptor function. Mol Pharmacol (2006) 70:1700-7. doi:10.1124/ mol.106.028035

66. Vandamme W, Braet K, Cabooter L, Leybaert L. Tumour necrosis factor alpha inhibits purinergic calcium signalling in blood-brain barrier endothelial cells. J Neurochem (2004) 88:411-21. doi:10.1046/j.1471-4159.2003.02163.x

67. Lohman AW, Leskov IL, Butcher JT, Johnstone SR, Stokes TA, Begandt D, et al. Pannexin 1 channels regulate leukocyte emigration through the venous endothelium during acute inflammation. Nat Commun (2015) 6:7965. doi:10.1038/ ncomms 8965

68. Sathanoori R, Sward K, Olde B, Erlinge D. The ATP receptors P2X7 and $\mathrm{P} 2 \mathrm{X} 4$ modulate high glucose and palmitate-induced inflammatory responses in endothelial cells. PLoS One (2015) 10:e0125111. doi:10.1371/journal. pone. 0125111

69. Kang J, Kang N, Lovatt D, Torres A, Zhao Z, Lin J, et al. Connexin 43 hemichannels are permeable to ATP. J Neurosci (2008) 28:4702-11. doi:10.1523/ JNEUROSCI.5048-07.2008

70. Schalper KA, Sanchez HA, Lee SC, Altenberg GA, Nathanson MH, Saez JC. Connexin 43 hemichannels mediate the $\mathrm{Ca} 2+$ influx induced by extracellular alkalinization. Am J Physiol Cell Physiol (2010) 299:C1504-15. doi:10.1152/ ajpcell.00015.2010

71. Schulz R, Heusch G. Connexin 43 and ischemic preconditioning. Cardiovasc Res (2004) 62:335-44. doi:10.1016/j.cardiores.2003.12.017

72. Gonca E, Darici F. The effect of cannabidiol on ischemia/reperfusion-induced ventricular arrhythmias: the role of adenosine A1 receptors. JCardiovasc Pharmacol Ther (2015) 20:76-83. doi:10.1177/1074248414532013

73. Hao E, Mukhopadhyay P, Cao Z, Erdelyi K, Holovac E, Liaudet L, et al. Cannabidiol protects against doxorubicin-induced cardiomyopathy by modulating mitochondrial function and biogenesis. Mol Med (2015) 21:38-45. doi:10.2119/molmed.2014.00261

74. Rajesh M, Mukhopadhyay P, Batkai S, Hasko G, Liaudet L, Huffman JW, et al. CB2-receptor stimulation attenuates TNF-alpha-induced human endothelial cell activation, transendothelial migration of monocytes, and monocyte-endothelial adhesion. Am J Physiol Heart Circ Physiol (2007) 293:H2210-8. doi:10.1152/ajpheart.00688.2007

75. Sanchez-Pastor E, Andrade F, Sanchez-Pastor JM, Elizalde A, Huerta M, Virgen-Ortiz A, et al. Cannabinoid receptor type 1 activation by arachidonylcyclopropylamide in rat aortic rings causes vasorelaxation involving calcium-activated potassium channel subunit alpha-1 and calcium channel, voltage-dependent, L type, alpha 1C subunit. Eur JPharmacol (2014) 729:100-6. doi:10.1016/j.ejphar.2014.02.016

76. Gruden G, Barutta F, Kunos G, Pacher P. Role of the endocannabinoid system in diabetes and diabetic complications. Br J Pharmacol (2016) 173:1116-27. doi:10.1111/bph.13226

77. Cohen K, Weinstein AM. Synthetic and non-synthetic cannabinoid drugs and their adverse effects-a review from public health prospective. Front Public Health (2018) 6:162. doi:10.3389/fpubh.2018.00162

78. De Bock M, Decrock E, Wang N, Bol M, Vinken M, Bultynck G, et al. The dual face of connexin-based astroglial $\mathrm{Ca}(2+)$ communication: a key player in brain physiology and a prime target in pathology. Biochim Biophys Acta (2014) 1843:2211-32. doi:10.1016/j.bbamcr.2014.04.016

79. Choi J, Hammer LW, Hester RL. Calcium-dependent synthesis of prostacyclin in ATP-stimulated venous endothelial cells. Hypertension (2002) 39:581-5. doi:10.1161/hy0202.103289

80. Moccia F, Baruffi S, Spaggiari S, Coltrini D, Berra-Romani R, Signorelli S, et al. $\mathrm{P} 2 \mathrm{y} 1$ and $\mathrm{P} 2 \mathrm{y} 2$ receptor-operated Ca2+ signals in primary cultures of cardiac microvascular endothelial cells. Microvasc Res (2001) 61:240-52. doi:10.1006/ mvre.2001.2306

81. Heiss C, Rodriguez-Mateos A, Kelm M. Central role of eNOS in the maintenance of endothelial homeostasis. Antioxid Redox Signal (2015) 22:1230-42. doi:10.1089/ars.2014.6158

82. Forstermann U, Sessa WC. Nitric oxide synthases: regulation and function. Eur Heart J (2012) 33:829-37, 837a-d. doi:10.1093/eurheartj/ehr304

83. Shu X, Keller TCT, Begandt D, Butcher JT, Biwer L, Keller AS, et al. Endothelial nitric oxide synthase in the microcirculation. Cell Mol Life Sci (2015) 72:4561-75. doi:10.1007/s00018-015-2021-0

84. Cosentino F, Hishikawa K, Katusic ZS, Luscher TF. High glucose increases nitric oxide synthase expression and superoxide anion generation in human aortic endothelial cells. Circulation (1997) 96:25-8. doi:10.1161/01. CIR.96.1.25

85. Scherrer U, Randin D, Vollenweider P, Vollenweider L, Nicod P. Nitric oxide release accounts for insulin's vascular effects in humans. J Clin Invest (1994) 94:2511-5. doi:10.1172/JCI117621

86. Zeng GY, Quon MJ. Insulin-stimulated production of nitric oxide is inhibited by wortmannin - direct measurement in vascular endothelial cells. J Clin Invest (1996) 98:894-8. doi:10.1172/JCI118871

87. Salt IP, Morrow VA, Brandie FM, Connell JM, Petrie JR. High glucose inhibits insulin-stimulated nitric oxide production without reducing endothelial nitric-oxide synthase Ser1177 phosphorylation in human aortic endothelial cells. J Biol Chem (2003) 278:18791-7. doi:10.1074/jbc.M210618200

88. Andreozzi F, Laratta E, Procopio C, Hribal ML, Sciacqua A, Perticone M, et al. Interleukin-6 impairs the insulin signaling pathway, promoting production of nitric oxide in human umbilical vein endothelial cells. Mol Cell Biol (2007) 27:2372-83. doi:10.1128/MCB.01340-06

Conflict of Interest Statement: The authors declare that the research was conducted in the absence of any commercial or financial relationships that could be construed as a potential conflict of interest.

Copyright (C) 2018 Sáez, Contreras-Duarte, Gómez, Labra, Santibañez, GajardoGómez, Avendaño, Díaz, Montero, Velarde and Orellana. This is an open-access article distributed under the terms of the Creative Commons Attribution License (CC $B Y)$. The use, distribution or reproduction in other forums is permitted, provided the original author(s) and the copyright owner(s) are credited and that the original publication in this journal is cited, in accordance with accepted academic practice. No use, distribution or reproduction is permitted which does not comply with these terms. 